\title{
Modulation of Diabetes by Natural Products and Medicinal Plants via Incretins
}

Authors

José-Luis Ríos ${ }^{1}$, Isabel Andújar ${ }^{1,2}$, Guillermo R. Schinella ${ }^{3}$, Flavio Francini ${ }^{4}$

\section{Affiliations}

1 Departament de Farmacologia, Universitat de València, Valencia, Spain

2 Departamento de Ciencias Biomédicas, Universidad Europea de Valencia, Valencia, Spain

3 Cátedra Farmacología Básica, Facultad de Ciencias Médicas UNLP and CICPBA, La Plata, Argentina

4 CENEXA; UNLP-CONICET La Plata-FCM; CEAS-CICPBA, La Plata, Argentina

Key words

incretins, glucagon-like peptide-1, GLP-1, glucose-dependent insulinotropic polypeptide, GIP, dipeptidyl peptidase-4, DPP-4

received February 5, 2019

revised April 17, 2019

accepted April 22, 2019

Bibliography

DOI https://doi.org/10.1055/a-0897-7492

Published online May 7, 2019 | Planta Med 2019; 85: 825-

839 @ Georg Thieme Verlag KG Stuttgart · New York |

ISSN 0032-0943
Correspondence

Prof. Dr. José-Luis Ríos

Departament de Farmacologia, Facultat de Farmàcia,

Universitat de València

Vicent Andrés Estellés s/n, 46100 Burjassot, Valencia, Spain

Phone: + 34963544973 , Fax: + 34963544943

riosjl@uv.es

\section{ABSTRACT}

Incretins are metabolic hormones released after a meal that increase insulin secretion from pancreatic $\beta$-cells. The two main incretins are the intestinal peptides glucagon-like peptide- 1 and glucose-dependent insulinotropic polypeptide. Both induce a decrease in glycemia, slow down the absorption of nutrients, and are inactivated by the enzyme dipeptidyl peptidase-4. Recently, incretin-based therapies have become a useful tool to treat diabetic patients, and different studies have focused on the identification of glucagon-like peptide- 1 receptor agonists, including those of natural origin. This review focuses on the new findings of medicinal plants and natural products as possible active agents on the potentiation of incretin receptor signaling. Among these, soluble fiber from species of Plantago and guar gum show promising effects, iridoid derivatives are relevant activators of incretin receptors, and derivatives of cyanidin, especially diglycosylated ones, are an interesting source of dipeptidyl peptidase-4 inhibitors.

$\begin{array}{ll}\text { ABBREVIATIONS } \\ \text { DPP-4 } & \text { dipeptidyl peptidase-4 } \\ \text { FDA } & \text { Food and Drug Administration } \\ \text { GIP } & \text { glucose-dependent insulinotropic polypeptide } \\ \text { GLP-1 } & \text { glucagon-like peptide-1 } \\ \text { GLUT } & \text { glucose transporter } \\ \text { IDX-1 } & \text { islet/duodenum homeobox-1 } \\ \text { i.p. } & \text { intraperitoneal } \\ \text { i.v. } & \text { intravenous } \\ \text { PEPCK } & \text { phosphoenolpyruvate carboxykinase } \\ \text { SGLT } & \text { sodium-glucose linked transporter } \\ \text { T2D } & \text { type 2 diabetes mellitus } \\ \text { TGR5 } & \text { Takeda G-protein-coupled receptor 5 }\end{array}$

\section{Introduction}

When glucose is administrated orally, the insulin secretion response is two- to threefold higher than the response elicited by a comparable intravenous glucose administration, a phenomenon denominated "incretin effect". Incretins are peptide hormones that are rapidly released in the gut in response to food and, together with an increase in blood glucose, stimulate insulin secretion [15]. GIP and GLP-1 are the most representative incretin hormones secreted by the upper (GIP, K cells) and lower (GLP-1, L cells) gut $[4,5]$. In the blood, GLP-1 can be found as two molecular forms with equivalent effects, GLP-1(7-37) and GLP-1(7-36)amide, with the latter being predominant in the blood after a meal [6].

In the fasted state, the GLP-1 circulating level is low, but increases after eating ( $\triangleright$ Fig. 1A). However, both GLP-1 and GIP have a short half-life, quickly decreasing due to enzymatic degra- 
dation by DPP-4 ( $\bullet$ Fig. 1 B) together with renal clearance [6]. This situation can be pharmacologically modified by employing two approaches: (1) using DPP-4 inhibitors such as sitagliptin and vildagliptin that preserve native GLP-1 or (2) with DPP-4-resistant GLP-1 analogs ( $\bullet$ Fig.1C), such as exenatide and liraglutide, among others $[7,8]$.

In the pathogenesis of T2D and in its initial stage, altered glucose tolerance, experimental evidence shows a significant decrease in the incretin effect [9-11]. Interestingly, the insulinotropic and glucagonostatic effects of GLP-1 are well preserved in T2D patients, and the pharmacological stimulation of GLP-1 receptors significantly improves glycemic control $[4,6]$.

GLP-1 exerts several effects in different organs or systems. Among them, it is important to mention the reduction in appetite and food intake, thus leading to weight loss in the long term. This fact, together with the key finding that GLP-1 secretion seems to be impaired in obese subjects, suggests a pathogenic role in obesity [4].

The effects of GIP and GLP-1 are related to the activation of structurally different receptors associated with $G$ proteins, located in different organs, including the stomach, hypothalamus, and endocrine pancreas [2,3,12-14]. Activation of these receptors on pancreatic $\beta$-cells increases cAMP and cytosolic $\mathrm{Ca}^{2+}$ levels, which in turn increases insulin secretion in response to oral glucose administration $[3,15]$. Sustained activation of this pathway leads to the activation of protein kinase $A$, gene expression, and enhanced insulin synthesis, together with stimulation of $\beta$-cell replication [16]. GLP-1 also inhibits glucagon secretion $[2,17$, 18]. An additional site of action has also been demonstrated for GLP-1, which is the hepatoportal glucose "sensor" that is activated whenever a glucose gradient is established between the portal region and the periphery as it occurs in the postprandial period [19]. Glucose detection by the abovementioned sensor requires not only a GLUT but also an activated GLP-1 receptor, in turn establishing a gluco-incretin receptor system of physiological relevance [19].

Additionally, GLP-1 inhibits gastric emptying and food ingestion, and enhances glucose disposal by neural mechanisms, contributing to glucose homeostasis [20]. GIP and GLP-1 also have effects on adipose cells, bone, and the cardiovascular system. Regarding the latter, recent findings suggest that GLP-1 receptor agonists, such as liraglutide, reduce cardiovascular events and prolong life in high-risk patients with T2D [4].

Although the evidence is not complete, GLP-1 receptors have also been identified in hepatocytes of rodents and humans [21, 22 ], and it has been postulated that their activation would directly reduce hepatic steatosis in several experimental models $[23,24]$. These effects could be possibly mediated via activation of the insulin signaling cascade [21] as well as the AMPK pathway [25]. In this sense, Svegliati-Baroni et al. [22] showed that not only would there be receptors for GLP-1 in human hepatocytes, but their number would be decreased in patients with nonalcoholic steatohepatitis. Despite these evidences, other authors suggest that different peptides derived from the degradation of GLP-1 would act through an independent pathway of the receptor, directly at the mitochondrial level through the modulation of phosphorylation and oxidative stress [26-28]. In addition, it has been shown that

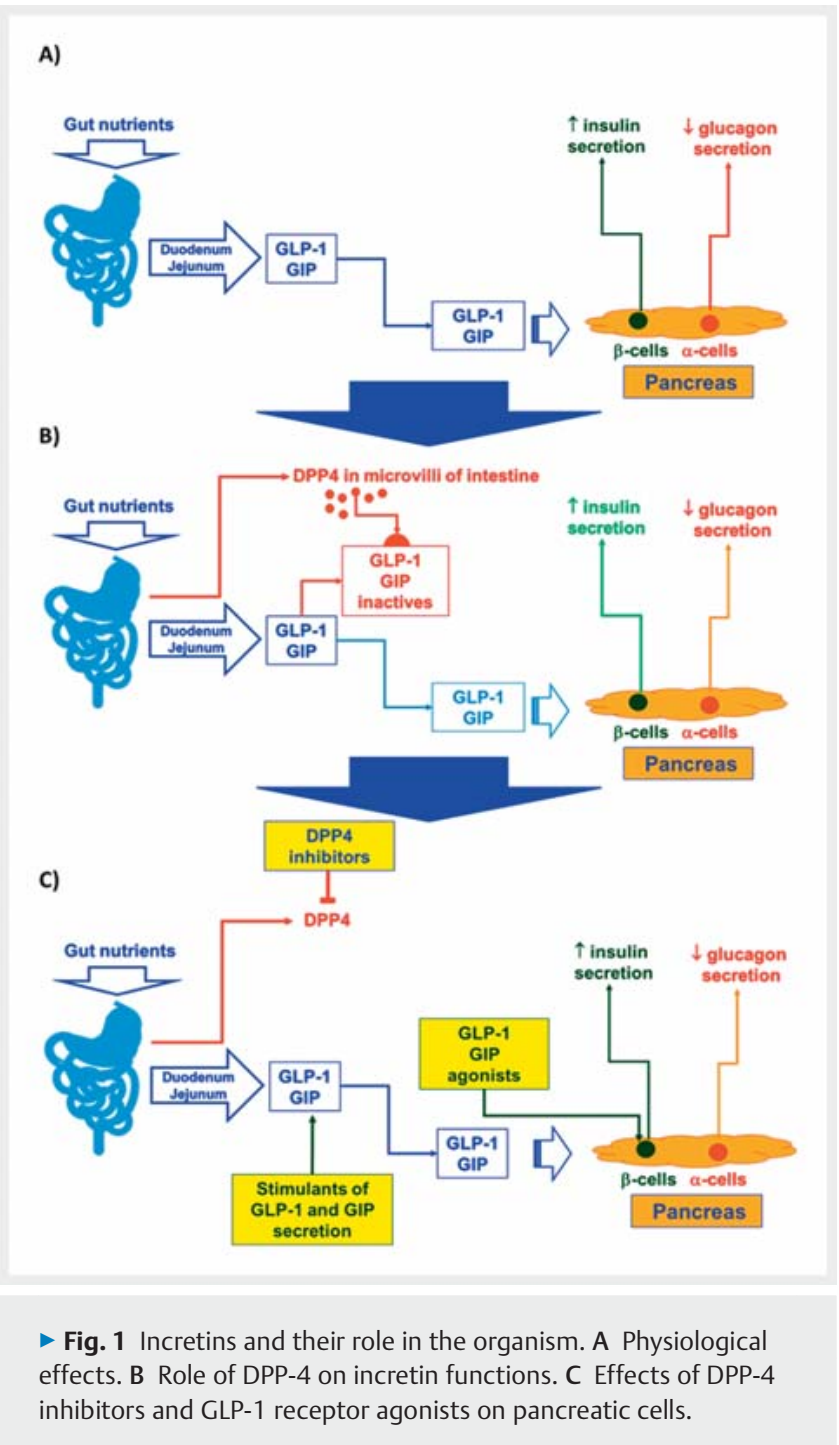

GLP-1 has a protective effect from oxidative stress in endothelial cells both in vivo [29] and in vitro [30]. In summary, incretin hormones have been proven to be key players in the pathophysiology of obesity and T2D, and, in consequence, they have very high therapeutic potential [31,32].

Several interesting approaches have been proposed for treating T2D, and these antidiabetic agents act with different or similar mechanisms of action [33]. The use of biguanide and its derivatives to treat diabetes can be traced back to the Middle Ages, when administration of the aerial parts of Goat's Rue herb (Galega officinalis L., Leguminosae) infusions was a common practice. Galegin, isolated from this plant, became the main compound of several from which metformin was synthesized [34]. These studies continued until 1994, when the U.S. FDA approved metformin for the treatment of T2D. This compound was shown to delay the progression of T2D, reduce the risk of complications and mortality by decreasing hepatic glucose synthesis from non-glycidic substrates, and sensitize tissues to insulin. Since then, metformin has been the first-choice oral drug in the treatment of T2D [35]. However, in circumstances where metformin is contraindicated or not 
tolerated, a second-line agent must be used. In these cases, GLP-1 agonists and/or DPP-4 inhibitors are an option [8,36-38]. These recently approved classes of therapeutic agents for the treatment of T2D exert their actions through the potentiation of incretin receptor signaling or by expanding the half-life of GLP-1 [6].

In 2005, the FDA approved the first incretin mimetic, exenatide, originally isolated from the salivary secretions of the Gila monster (Heloderma suspectum), a venomous lizard from the western U.S.A. and Mexico [39]. Exenatide is a GLP-1 receptor analogue resistant to DPP-4 degradation used as adjunctive therapy for patients with T2D. Because GLP-1 analogues require injection, considerable effort has been devoted to creating an oral agent able to target the incretin pathway. Inhibition of DPP-4 extends the half-life of native incretins, thereby prolonging their effects. In 2006, the FDA approved the first oral incretin enhancer, sitagliptin, a selective DPP-4 inhibitor, for use as monotherapy or in combination with metformin or thiazolidinedione [6]. Since then, this new class of hypoglycemic agents is subject to continuous evaluations of efficacy and safety [40-45].

In recent years, incretin-based therapies have become an important treatment option for patients with T2D. In order to improve the various issues related to the efficacy and safety of these drugs, the search for new drugs is necessary. Recently, studies have focused on identifying non-peptidic agonists for the GLP-1 receptor $[46,47]$. For this reason, the aim of this review is to present new findings of medicinal plants and natural products that exert their actions through potentiation of incretin receptor signaling.

\section{The Use of Food for the Control of Diabetes through Incretin Increase}

The main use of natural products for the control of glycemia was through food. In the 1990s, different studies compared the effects of fatty acids on glucose, insulin, GIP, and GLP-1 levels. For example, Thomsen et al. $[48,49]$ studied the effect of olive oil, comparing it with butter, on the levels of glucose, insulin, and fatty acids, and demonstrated that this oil induced lower triacylglycerol concentrations and higher HDL-cholesterol concentrations than butter. No clear differences were observed in glycemia or insulinemia, although higher concentrations of GLP-1 and GIP were observed with the use of monounsaturated versus saturated fatty acids, suggesting a relation between fatty acid composition, incretin responses, and triacylglycerol postprandial metabolism in patients with T2D [49]. In the same line, Iritani et al. [50] demonstrated that oral triacylglycerols stimulated GLP-1 secretion in the gut lumen and produced a second insulin peak at $4 \mathrm{~h}$. These effects were corroborated by Prieto et al. [51] and by Cancelas et al. [52], who observed that an olive oil-enriched diet increases both GLP-1 release and the secretory response of insulin-producing cells to oral glucose administration, improving glucose tolerance in Wistar rats [51] and in an animal model of T2D (adult rats injected with streptozotocin during the neonatal period) [52]. The group of Professor Tso observed that incretins are in a higher concentration in intestinal lymph versus plasma $[53,54]$ and, using a lymph fistula rat model, they tested the dose-dependent relation- ship between the secretion of GIP and GLP-1 and dietary lipids, showing that the intraluminal lipid content was greater in GLP-1than in GIP-secreting cells [55]. In contrast, another study of interest [56] demonstrated that the GLP-1 level and glycemia were not affected by omega-3 fatty acid supplementation. In this study, the researchers tested both fish oil (enriched in eicosapentaenoic acid and docosahexaenoic acid) and flaxseed (Linum usitatissimum L., Linaceae) oil (enriched in $\alpha$-linolenic acid) on Sprague-Dawley rats for 7 weeks.

The incretin effect after lipid consumption in humans was studied by Lindgren et al. [57] and Manning et al. [58]. Lindgren's group orally administered a lipid emulsion (Intralipid, $3 \mathrm{~mL} / \mathrm{kg}$ ) and observed an increase in total and intact GIP and GLP-1 levels. However, when they administered the lipids i.v., no significant modifications were detected, concluding that oral lipid ingestion elicits a clear insulin response in association with increased GIP and GLP-1 concentrations. To test the differences between cooking with unheated sunflower (Helianthus annuus L., Compositae) oil and thermally oxidized sunflower oil, Manning et al. [58] measured the plasma concentrations of GLP-1. There were no significant differences in plasmatic GLP-1 concentrations while eating either meals; however, the concentration was significantly increased from 30 min to a peak at 60 min after the ingestion of an unheated sunflower oil-cooked meal versus the thermally oxidized sunflower oil-cooked meal.

Another edible plant, beets (Beta vulgaris L., Amaranthaceae), was tested as a potential antidiabetic medicinal plant. Indeed, the aqueous extract of $B$. vulgaris (whole plant) was the only active fraction $(50 \mathrm{mg} / \mathrm{kg})$ from a hydroethanolic extract fractioned with solvents of different polarity. Administration of this extract at different doses to T2D mice $(d b / d b)$ significantly increased GLP-1 and enhanced insulin secretion, confirming the antihyperglycemic activity of this plant [59].

\section{Medicinal Plant Products and Their Effect on Incretin Secretion}

Some researchers focus their studies on natural fractions from medicinal plants. This is the case of Ellis et al. [60] and Gatenby et al. [61], who have demonstrated that guar gum, at concentrations found in the diet ( 20 or $40 \mathrm{~g} / \mathrm{kg}$ ), reduces glucose absorption and insulin and GIP secretion during the postprandial period ( $4 \mathrm{~h}$ ) [60], and that $7.6 \mathrm{~g}$ of guar gum per meal attenuate insulinemia in diabetic patients by increasing hepatic extraction of insulin [61]. More recently, den Besten et al. [62] demonstrated in both humans and rodents that this beneficial effect of guar gum was mediated by the short-chain fatty acids produced by colonic fermentation. These short-chain fatty acids stimulate GLP-1 release, increasing peripheral glucose clearance.

Another type of dietary fiber, soluble fiber from Plantago indica L. (syn: Plantago psyllium L., Plantaginaceae) was studied by Karhunen et al. [63] in humans obtaining similar results. Fiber-enriched meals decreased glycemia and insulinemia in healthy young adults by strongly modifying postprandial signals arising from the gastrointestinal tract. Postprandial GLP-1 concentrations increased for 20 min after the white wheat bread, low-fiber, and 
low-protein meals, and then the concentrations returned gradually toward the baseline. In contrast, the GLP-1 concentration after the fiber and protein-rich meal decreased below the baseline for the entire experimental period.

Other products with high interest are those containing phenolic compounds, such as coffee and its main phenolic, chlorogenic acid. It is largely known that dietary phenolics have positive effects on the pattern of glucose uptake in the small intestine. In this sense, Johnston et al. [64] observed the effects of caffeine and chlorogenic acid from coffee on glycemia, insulinemia, and GIP and GLP-1 secretion, modifying intestinal glucose absorption. Other authors established that a supplement of chlorogenic acid (e.g., as green decaffeinated coffee) lowers the glycemic index of meals and increase GLP-1, reducing the risk for diabetes [65]. However, Esatbeyoglu et al. [66] studied different phenolic derivatives from deep purple carrots [Daucus carota subsp. sativus (Hoffm.) Arcang. var. atrorubens Alef., Apiaceae], such as the anthocyanin fraction, primarily phenolic acids and chlorogenic acid, but none of them affected GLP-1 secretion and DPP-4 activity. Overall, the phenolic fraction exhibited an inhibitory effect on $\alpha$ amylase and $\alpha$-glucosidase activity and on cellular glucose uptake, indicating potential antidiabetic properties.

Sweet potato [Ipomoea batatas (L.) Lam., Convolvulaceae] leaves contain polyphenols such as caffeoylquinic acid derivatives. Nagamine et al. [67] studied the effect of sweet potato leaf extract powder on hyperglycemia in type 2 diabetic mice and observed that, after five weeks, the extract lowered glycemia. When testing both the sweet potato leaf extract powder and its caffeoylquinic acid derivatives in vitro, they found enhanced GLP-1 secretion, demonstrating that the effect of sweet potato leaf extract powder is mediated by the caffeoylquinic acid derivatives, which attenuate postprandial hyperglycemia through the enhancement of GLP-1.

\section{Potentiality of Medicinal Plants as Incretin Modulators}

Aside from food, medicinal plants have been used as a potential source of antidiabetic agents, and many of them are of interest as modulators of incretins. There are complete and good reviews, such as the revision of Hung et al. [68] and Eddouks et al. [69], on the discovery of plant-derived antidiabetic natural products, which cover the years from 2005 to 2010 and until 2013, respectively, but no references on incretins were included. However, some articles describing this activity during this period were published $[60,61,70]$. Ribnicky et al. [70] analyzed the effect of Tarralin, an ethanolic extract of Russian tarragon (Artemisia dracunculus L., Compositae), as a potential antihyperglycemic drug in genetically diabetic KK-A ${ }^{\gamma}$ mice and nondiabetic animals. Oral administration of this extract $(500 \mathrm{mg} / \mathrm{kg} / \mathrm{d}$ for 1 week) decreased blood glucose levels by $24 \%$ in respect to the negative control, whereas positive controls troglitazone $(30 \mathrm{mg} / \mathrm{kg} / \mathrm{d})$ and metfor$\min (300 \mathrm{mg} / \mathrm{kg} / \mathrm{d})$ lowered glycemia by 28 and $41 \%$, respectively. Insulinemia was also reduced in diabetic mice by $33 \%$ with the extract, whereas its combination with troglitazone or metformin reduced it by 48 and $52 \%$, respectively. The authors hypothesized a possible mechanism of action and what the active principles would be, but these were not tested. Moreover, the extract decreased PEPCK mRNA expression in streptozotocin-induced diabetic rats, but PEPCK expression was not affected in nondiabetic rats. In fact, it did not modify glycemia or insulinemia in nondiabetic rats, but it did increase the binding of GLP-1 to its receptor in vitro. For this reason, the authors proposed the potential use of Tarralin as a supplement for the management of glycemia and insulin resistance in diabetic patients [70]. Other authors, such as the Park et al. [71], investigated the effects of different medicinal plants used in Chinese medicine with interesting results; however, they used mixtures of crude drugs and it is not easy to establish the potentiality of each of them.

It is known that yerba mate (Ilex paraguariensis A. St.-Hil., Aquifoliaceae) has antidiabetic properties [34]. In this sense, Hussein et al. [72] investigated an aqueous extract of mate on diabetes and metabolic syndrome effects in a mouse model. The extract $(50,100 \mathrm{mg} / \mathrm{kg})$ was administered orally for 3 weeks and a significant increase in GLP-1 was observed. Moreover, acute administration of the principal constituents of mate, dicaffeoyl quinic acids and matesaponins, also produced a significant increase in GLP-1 levels, suggesting that yerba mate exerts anorexic effects by direct induction of satiety and by stimulation of GLP-1 secretion, as well as by modulating leptin levels. As mentioned earlier, these same compounds, caffeoylquinic acid derivatives, were also described as the active principles of sweet potato leaves [67].

Kubow et al. [73] tested a phenolic-rich potato (Solanum tuberosum L., Solanaceae) extract (final concentration: 1.93 or $3.5 \%, w / w)$ in $(57 B L / 6$ J mice with a high-fat diet for 10 weeks. This extract attenuated weight gain by $63 \%$ in both male and female mice, an effect associated with a reduction in adiposity, but sex differences were observed in GIP as well as other metabolic indicators (insulin, ghrelin, leptin, and resistin). These differences were not observed in other experiments with phenolics. Previously, Raasmaja et al. [74] demonstrated a decrease in circulating GLP-1 in genetically obese Zucker rats fed with a high-fat/highcholesterol diet after the administration of a $70 \%$ ethanol extract (obtained from a water extract) of Citrus maxima (Burm.) Merr. [syn: Citrus grandis (L.) Osbeck, Rutaceae] at 300, 600, and $1200 \mathrm{mg} / \mathrm{kg}$, which could be related with an increase in glucagon and glucose levels, as well as a decrease in the insulin level.

Bitter melon (Momordica charantia L., Cucurbitaceae) has been reported as an antidiabetic fruit, but similar properties have also been demonstrated for other parts of this plant [34]. Several metabolites, such as $\alpha$-eleostearic acid or a Zn-free protein, and mechanisms have been described; however, the implication of GLP-1 was not analyzed. In this way, Bhat et al. [75] recently studied the effect of an aqueous extract $(300 \mathrm{mg} / \mathrm{kg} / \mathrm{d}$ for $28 \mathrm{~d}$ ) of bitter melon on both normal and diabetic Wistar rats, demonstrating that this extract increased insulinemia and GLP-1 in normal (nonsignificant) and in diabetic Wistar rats (significant, $\mathrm{p}<0.01$ ). This effect was associated to elevated $\beta$-cell proliferation and insulin secretion.

The main medicinal plants and some of their relevant fractions are compiled in $>$ Table $\mathbf{1}$, including plant material investigated, extracts used, concentration, protocols employed, and effects obtained in the experiments. 
- Table 1 Medicinal plants as incretin modulators.

\begin{tabular}{|c|c|c|c|c|c|}
\hline Plant & Extract & Concentration & Protocol & Effects & Ref \\
\hline $\begin{array}{l}\text { Artemisia } \\
\text { dracunculus }\end{array}$ & $\begin{array}{l}\text { Tarralin } \\
\text { (commercial) }\end{array}$ & $\begin{array}{l}\text { Ethanolic extract } \\
500 \mathrm{mg} / \mathrm{kg} / \mathrm{d}\end{array}$ & $\begin{array}{l}\text { Diabetic KK-Ay mice } \\
\text { and diabetic rats }\end{array}$ & $\begin{array}{l}\text { Reduces glycemia and insulinemia, } \\
\text { and PEPCK mRNA expression }\end{array}$ & {$[70,71]$} \\
\hline Citrus maxima & Dried fruits & $\begin{array}{l}70 \% \text { Ethanol extract obtained } \\
\text { from a water extract } \\
300,600 \text {, and } 1200 \mathrm{mg} / \mathrm{kg}\end{array}$ & $\begin{array}{l}\text { Genetically obese } \\
\text { Zucker rats }\end{array}$ & Decrease of circulating GLP-1 & [74] \\
\hline Coffea arabica & $\begin{array}{l}\text { Green decaffei- } \\
\text { nated coffee }\end{array}$ & $\begin{array}{l}400 \mathrm{~mL} \text { Decaffeinated coffee } \\
\text { (equivalent to } 2.5 \mathrm{mmol} \\
\text { chlorogenic acid/L) }\end{array}$ & $\begin{array}{l}\text { Healthy fasted } \\
\text { volunteers }\end{array}$ & $\begin{array}{l}\text { Lowers the glycemic index of meals } \\
\text { and increase GLP-1 }\end{array}$ & {$[65]$} \\
\hline $\begin{array}{l}\text { Cyamopsis } \\
\text { tetragonoloba }\end{array}$ & Guar gum & 20 and $40 \mathrm{mg} / \mathrm{kg}$ & Human - diet & $\begin{array}{l}\text { Reduces glucose absorption, } \\
\text { and insulin and GIP secretion }\end{array}$ & {$[60]$} \\
\hline $\begin{array}{l}\text { Cyamopsis } \\
\text { tetragonoloba }\end{array}$ & Guar gum & $7.6 \mathrm{~g}$ per meal & Diabetic patients & $\begin{array}{l}\text { Attenuates insulinemia by increasing } \\
\text { the hepatic extraction of insulin }\end{array}$ & {$[61]$} \\
\hline $\begin{array}{l}\text { Cyamopsis } \\
\text { tetragonoloba }\end{array}$ & Guar gum & $\begin{array}{l}\text { High-fat diet supplemented } \\
\text { with } 10 \% \text { guar gum } / 12 \text { weeks }\end{array}$ & C57BI/6 J mice & $\begin{array}{l}\text { Short-chain fatty acids produced by } \\
\text { colonic fermentation stimulate GLP-1 } \\
\text { release, increasing peripheral glucose } \\
\text { clearance }\end{array}$ & {$[62]$} \\
\hline $\begin{array}{l}\text { Daucus carota } \\
\text { subsp. sativus } \\
\text { var. atrorubens }\end{array}$ & $\begin{array}{l}\text { Anthocyanin } \\
\text { fractions }\end{array}$ & $\begin{array}{l}\text { Anthocianidins }(50 \mu \mathrm{g} / \mathrm{mL}) \text { and } \\
\text { chlorogenic acid }(17.7 \mu \mathrm{g} / \mathrm{mL})\end{array}$ & GLUTag cells & $\begin{array}{l}\text { Inhibitory effect on } \alpha \text {-amylase and } \\
\alpha \text {-glucosidase activity, but no effect } \\
\text { on GLP-1 secretion and DPP- } 4 \text { activity }\end{array}$ & {$[66]$} \\
\hline $\begin{array}{l}\text { Gentiana } \\
\text { scabra }\end{array}$ & Whole plant & $\begin{array}{l}\text { Water extract } \\
\text { in vitro } \mathrm{EC}_{50} 113.3 \mu \mathrm{g} / \mathrm{mL} \\
\text { in vivo } 100 \text { and } 300 \mathrm{mg} / \mathrm{kg}\end{array}$ & $\begin{array}{l}\text { NCl-H716 cells } \\
\text { Lepr }^{-1-}(d b / d b) \text { mice }\end{array}$ & Stimulates GLP-1 secretion & [88] \\
\hline $\begin{array}{l}\text { Ilex para- } \\
\text { guariensis }\end{array}$ & Leaves & $\begin{array}{l}\text { Water extract } \\
50 \text { and } 100 \mathrm{mg} / \mathrm{kg}\end{array}$ & Male ddY mice & Stimulates GLP-1 secretion & [72] \\
\hline $\begin{array}{l}\text { Ipomoea } \\
\text { batatas }\end{array}$ & $\begin{array}{l}\text { Leaf extract } \\
\text { and quinic acid } \\
\text { derivatives }\end{array}$ & $\begin{array}{l}\text { Extract } 10 \mathrm{mg} / \mathrm{mL} \\
\text { Compounds } 10 \mathrm{mM}\end{array}$ & $\begin{array}{l}\text { Diabetic mice } \\
\text { GLUTag cells }\end{array}$ & $\begin{array}{l}\text { Lowers glycemia and enhances GLP-1 } \\
\text { secretion }\end{array}$ & [67] \\
\hline $\begin{array}{l}\text { Momordica } \\
\text { charantia }\end{array}$ & Fruits & $\begin{array}{l}\text { Water extract }(300 \mathrm{mg} / \mathrm{kg} / \mathrm{d} \\
\text { for } 28 \mathrm{~d})\end{array}$ & Diabetic Wistar rats & Increases insulinemia and GLP-1 & {$[75]$} \\
\hline Plantago indica & $\begin{array}{l}\text { Fiber-enriched } \\
\text { meals }\end{array}$ & 23 g per meal & Healthy young adults & $\begin{array}{l}\text { Decreases glycemia and insulinemia, } \\
\text { and increases postprandial GLP-1 }\end{array}$ & {$[63]$} \\
\hline $\begin{array}{l}\text { Solanum } \\
\text { tuberosum }\end{array}$ & Potato & $\begin{array}{l}\text { Polyphenolic-rich extracts } 1.93 \\
\text { and } 3.5 \%(\mathrm{w} / \mathrm{w}) / \text { diet }\end{array}$ & C57BL/6 J mice & $\begin{array}{l}\text { Reduction in adiposity and } \\
\text { GIP secretion }\end{array}$ & [73] \\
\hline
\end{tabular}

\section{Medicinal Plants and Natural Products as Inhibitors of Dipeptidyl Peptidase-4}

Ríos et al. [34] reviewed the medicinal plants as enhancers of insulin secretion and pancreatic $\beta$-cell proliferation and cited different plants as possible activators of GLP- 1 and GIP or inhibitors of DPP-4. For example, different inulin-type fructans, such as those obtained from Cichorium intybus L. (Compositae) and Agave tequilana F.A.C.Weber (Asparagaceae), enhance colon production of GLP-1, whereas Pterocarpus marsupium Roxb. (Leguminosae) and Syzygium cumini (L.) Skeels (syn: Eugenia jambolana Lam., Myrtaceae) inhibited DPP-4. Indeed, because DPP-4 is an enzyme that inactivates incretins, its inhibition could increase their level. Searching for this effect, Kosaraju et al. [76] studied in vitro and in vivo the potential DPP-4 inhibition of three medicinal plants, Pterocarpus marsupium, Syzygium cumini, and Gymnema sylvestre (Retz.) R.Br. ex Sm. (Apocynaceae). Two of them, P. marsupium and S. cumini, inhibited DPP-4 (IC 50 of 274 and $279 \mu \mathrm{g} / \mathrm{mL}$, respectively), whereas $G$. sylvestre had an $\mathrm{IC}_{50}$ of $773 \mu \mathrm{g} / \mathrm{mL}$. The three species had a long duration as enzyme inhibitors, with half-lives of 462.3, 317.2, and $153.8 \mathrm{~min}$, respectively. In conclusion, the extracts increased GLP-1 levels, and maximum peaks of GLP-1 were appreciated at $2 \mathrm{~h}$ for $P$. marsupium and $S$. cumini, and at $1.5 \mathrm{~h}$ for $G$. sylvestre. In a parallel analysis with $P$. marsupium and S. cumini (200 and $400 \mathrm{mg} / \mathrm{kg}$, orally) on streptozotocin-treated Wistar rats, an increase in GLP-1 levels was observed [77].

Peptides from oat (Avena sativa L., Poaceae), buckwheat (Fagopyrum esculentum Moench, Polygonaceae), and highland barley [Hordeum aegiceras Nees ex Royle, syn: Hordeum vulgare var. trifurcatum (Schltdl.) Alef., Poaceae] were also studied for their capacity to inhibit DPP-4. All of them showed in vitro DPP-4 inhibitory activity, with $\mathrm{IC}_{50}$ values ranging from 0.13 to $8.15 \mathrm{mg} / \mathrm{mL}$. In total, more than 35 peptides were identified in the tryptic hydrolysates of oat globulin [78]. 
Fagonia cretica L. (Zygophyllaceae) and Hedera nepalensis K. Koch (Araliaceae) are used in folk medicine for the treatment of diabetes. To clarify the effect on this illness and its mechanism of action, Saleem et al. [79] analyzed in vitro the inhibitory effect on DPP-4 of both plants using a crude extract obtained by maceration with chloroform-methanol $(1: 1)$ during 7 days, and also tested five isolated compounds. Of them, the crude extract of $H$. nepalensis had the best activity $\left(\mathrm{IC}_{50}\right.$ of $\left.17.2 \mu \mathrm{g} / \mathrm{mL}\right)$, whereas the activity of $F$. cretica was lower $\left(\mathrm{IC}_{50}\right.$ of $\left.38.1 \mu \mathrm{g} / \mathrm{mL}\right)$. However, when the extracts were fractioned and purified, the activity did not improve. As an example, the ethyl acetate of $H$. nepalensis gave an $\mathrm{IC}_{50}$ of $34.4 \mu \mathrm{g} / \mathrm{mL}$ and the $n$-hexane fraction, an $\mathrm{IC}_{50}$ of $34.2 \mu \mathrm{g} / \mathrm{mL}$. Regarding the isolated compounds, the inhibitory activities on DPP-4 did not improve the activity of the original extracts, so the $\mathrm{IC}_{50}$ values were as follows: quinovic acid $30.7 \mu \mathrm{M}$, quinovic acid-3 $\beta$-O- $\beta$-D-glycopyranoside $57.9 \mu \mathrm{M}$, quinovic acid-3 $\beta$-O- $\beta$-D-glucopyranosyl- $(28 \rightarrow 1)-\beta$-D-glucopyranosyl ester $23.5 \mu \mathrm{M}$ ( $\triangleright$ Fig. 2), and stigmasterol $>100 \mu \mathrm{M}$, all of them from $F$. cretica. The triterpene lupeol from $H$. nepalensis was tested and showed an $\mathrm{IC}_{50}$ of $31.6 \mu \mathrm{M}$. Taking together these results, $F$. cretica and $H$. nepalensis could be considered as antidiabetic agents with potential significant DPP-4 inhibitory activity [79].

González-Abuín et al. [80] described that grape-seed procyanidin extract prevented a decrease in DPP-4 activity and modulated the gene expression of GLP-1 and its receptor in the hypothalamus, inferring that procyanidins can abrogate the effects of the cafeteria diet on intestinal GLP-1 production and DPP-4 activity. The administration of the enriched extract to healthy Wistar female rats induced a plasmatic increase in GLP-1, and a decrease in glycemia. They also assayed if this inhibition occurred in inner intestinal tissues close to GLP-1-producing cells, such as the endothelium of the capillaries, and tested the effects of the main compounds, such as catechin, epicatechin, B2 dimer, and gallic acid, demonstrating that they inhibit DPP-4 activity in endothelial HUVEC cells in an additive way. They concluded that procyanidins improve glycemia via GLP-1 secretion caused by the inhibition of the inner intestinal DPP-4 activity, increasing active GLP-1 levels, and, in consequence, affecting insulin release [81]. Sulaiman [82] also investigated the potential role of standardized grape-seed proanthocyanidin $(50 \mathrm{mg} / \mathrm{kg}$ ) on incretin effects as a response to the glucose load in healthy rats, both oral and i. p., and the results were compared with the values obtained with sitagliptin (40 mg/ $\mathrm{kg}$ ) and the negative control (vehicle). Both the treated group and the positive control improved hyperglycemia induced by oral glucose. The mechanism of proanthocyanidin was associated with an enhancement of the incretin effect of gut peptides, and the authors concluded that the possible action of proanthocyanidin is via DPP-4 inhibition.

Kozuka et al. [83] tested the juice of aronia berries (Aronia sp., Rosaceae) as DPP-4 inhibitors. Enzymatic activity was determined by fluorometry (excitation $380 \mathrm{~nm}$ and emission $440 \mathrm{~nm}$ ), and DPP-4 inhibition was performed using L-proline 4-methyl-coumaryl-7-amide (Pro-MCA) as the substrate in Tris- $\mathrm{HCl}(\mathrm{pH} 9.0)$. The results demonstrated that the juice of aronia berries inhibited DPP-4 indirectly, increasing GIP and GLP-1. Cyanidin 3,5-diglucoside ( $\bullet$ Fig. 3) was identified as the main active principle and
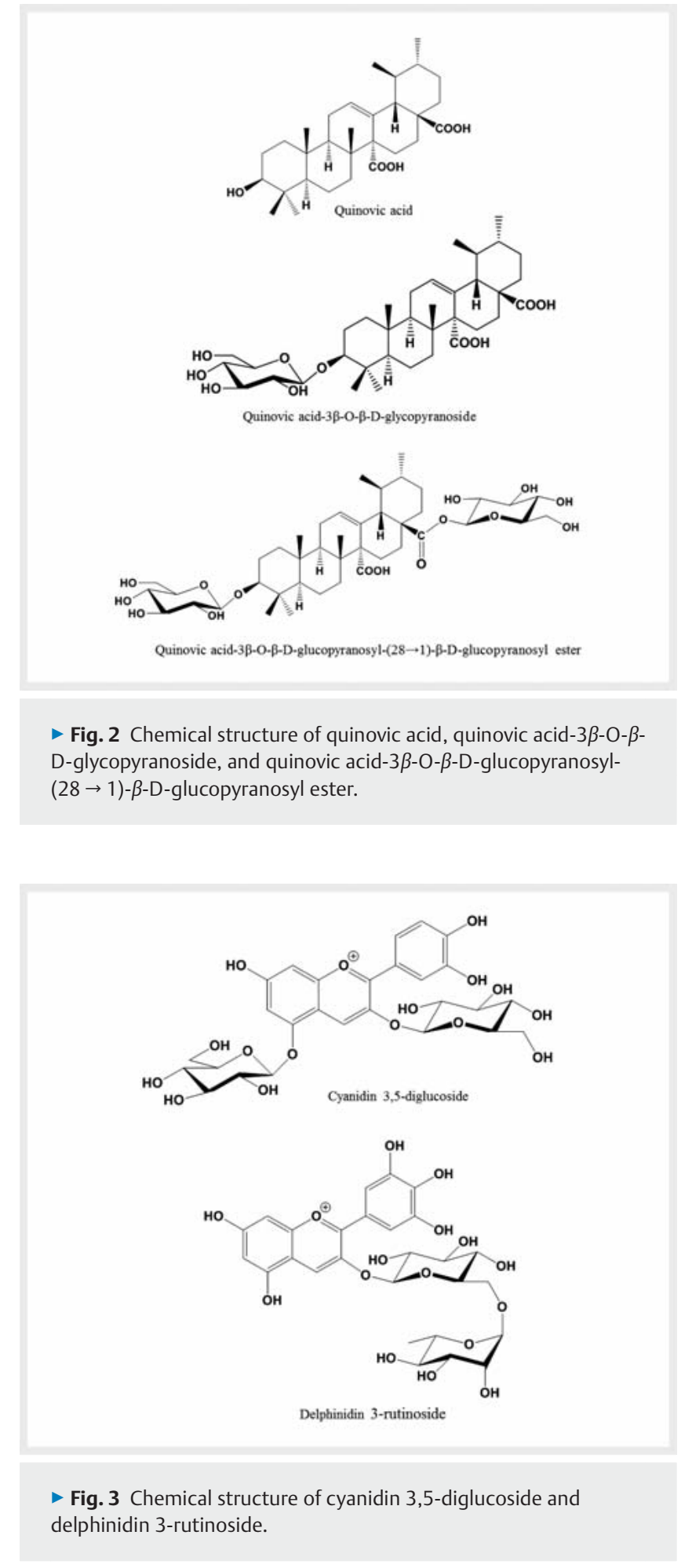

studied as a DPP-4 inhibitor. Although there are previous researches that identified cyanidin and cyanidin 3-glucoside as inhibitors of DPP-4, in the present study, the greater potency of cyanidin 3,5-diglucoside was demonstrated, giving an $\mathrm{IC}_{50}$ of $5.5 \mu \mathrm{M}$.

Relevant medicinal plants, their extracts, and concentrations are summarized in $>$ Table 2 , including their effects on DPP-4. 
- Table 2 Medicinal plants and natural products as inhibitors of DPP-4.

\begin{tabular}{|c|c|c|c|c|c|}
\hline Plant & Extract & Concentration & Protocol & Effects & Ref \\
\hline Aronia sp. & Juice fruits & No declared & $\begin{array}{l}\text { In vitro } \\
\text { DPP-4 + Gly-Pro-MCA }\end{array}$ & $\begin{array}{l}\text { DPP- } 4 \text { inhibition and } \\
\text { increase in GLP-1 and } \\
\text { GIP levels }\end{array}$ & [83] \\
\hline Avena sativa & $\begin{array}{l}\text { Extracts of seed } \\
\text { proteins }\end{array}$ & $\mathrm{IC}_{50} 0.99 \mathrm{mg} / \mathrm{mL}$ & $\begin{array}{l}\text { In vitro } \\
\text { DPP-4 + Gly Pro-pNA and peptide }\end{array}$ & Inhibition of DPP-4 & [78] \\
\hline Fagonia cretica & $\begin{array}{l}\text { Aerial parts } \\
\mathrm{CHCl}_{3}-\mathrm{MeOH}(1: 1)\end{array}$ & $\mathrm{IC}_{50} 38.1 \mu \mathrm{g} / \mathrm{mL}$ & $\begin{array}{l}\text { In vitro } \\
\text { DPP-4 + Gly Pro-AMC }\end{array}$ & Inhibition of DPP-4 & [79] \\
\hline Fagopyrum esculentum & $\begin{array}{l}\text { Extracts of seed } \\
\text { proteins }\end{array}$ & $\mathrm{IC}_{50} 1.98 \mathrm{mg} / \mathrm{mL}$ & $\begin{array}{l}\text { In vitro } \\
\text { DPP-4 + Gly Pro-pNA and peptide }\end{array}$ & Inhibition of DPP-4 & [78] \\
\hline Gymnema sylvestre & $\begin{array}{l}\text { Leaves } \\
100 \% \text { ethanol }\end{array}$ & $\mathrm{IC}_{50} 773 \mu \mathrm{g} / \mathrm{mL}$ & $\begin{array}{l}\text { In vitro } \\
\text { DPP-4 inhibitor screening assay kit }\end{array}$ & Inhibition of DPP-4 & [76] \\
\hline Hedera nepalensis & Aerial parts & $\mathrm{IC}_{50} 17.2 \mu \mathrm{g} / \mathrm{mL}$ & $\begin{array}{l}\text { In vitro } \\
\text { DPP-4 + Gly Pro-AMC }\end{array}$ & Inhibition of DPP-4 & [79] \\
\hline Hordeum aegiceras & $\begin{array}{l}\text { Extracts of seed } \\
\text { proteins }\end{array}$ & $\mathrm{IC}_{50} 3.91 \mathrm{mg} / \mathrm{mL}$ & $\begin{array}{l}\text { In vitro } \\
\text { DPP-4 + Gly Pro-pNA and peptide }\end{array}$ & Inhibition of DPP-4 & [78] \\
\hline $\begin{array}{l}\text { Pterocarpus } \\
\text { marsupium }\end{array}$ & $\begin{array}{l}\text { Heart wood } \\
100 \% \text { ethanol }\end{array}$ & $\begin{array}{l}\mathrm{I} C_{50} 274 \mu \mathrm{g} / \mathrm{mL} \\
200 \text { and } 400 \mathrm{mg} / \mathrm{kg}\end{array}$ & $\begin{array}{l}\text { In vitro } \\
\text { DPP- } 4 \text { inhibitor screening assay kit } \\
\text { STZ-treated Wistar rats }\end{array}$ & $\begin{array}{l}\text { DPP- } 4 \text { inhibition and } \\
\text { increase in GLP-1 levels }\end{array}$ & {$[76,77]$} \\
\hline Syzygium cumini & $\begin{array}{l}\text { Fruits } \\
100 \% \text { ethanol }\end{array}$ & $\begin{array}{l}\mathrm{IC}_{50} 279 \mu \mathrm{g} / \mathrm{mL} \\
200 \text { and } 400 \mathrm{mg} / \mathrm{kg}\end{array}$ & $\begin{array}{l}\text { In vitro: DPP-4 inhibitor screening } \\
\text { assay kit } \\
\text { In vivo: STZ-treated Wistar rats }\end{array}$ & $\begin{array}{l}\text { DPP- } 4 \text { inhibition and } \\
\text { increase in GLP-1 levels }\end{array}$ & {$[76,77]$} \\
\hline Vitis vinifera & $\begin{array}{l}\text { Grape-seed procyanidin } \\
\text { extract }\end{array}$ & $1 \mathrm{mg} / \mathrm{kg}$ & Healthy Wistar rats & $\begin{array}{l}\text { Increase of GLP-1, and } \\
\text { a decrease in glycemia }\end{array}$ & [81] \\
\hline Vitis vinifera & $\begin{array}{l}\text { Standardized grape- } \\
\text { seed proanthocyanidin }\end{array}$ & $50 \mathrm{mg} / \mathrm{kg}$ & Healthy Wistar rats & $\begin{array}{l}\text { DPP- } 4 \text { inhibition and } \\
\text { increase in GLP- } 1 \text { levels }\end{array}$ & [82] \\
\hline
\end{tabular}

\section{Natural Products as Stimulants of GLP-1 and GIP Secretion}

Jafri et al. [84] studied GLP-1 and GIP secretory activity of isolated compounds from Fagonia cretica in PGIP/neo STC-1 cells, which secrete both GLP-1 and GIP, and are potentially a very useful model for studying the secretory responses of both incretin hormones. Incretins were detected by GLP-1 and GIP ELISA kits. Intracellular levels of incretin hormones and their gene expression were also determined by the same protocol. The fresh aerial parts were extracted with chloroform/methanol $(1: 1)$ and the crude extract, as well as its $n$-hexane, ethyl acetate, and aqueous fractions (125 and $250 \mu \mathrm{g} / \mathrm{mL}$ ), stimulated both GLP-1 (3- to 55-fold) and GIP (1.6- to 2.2-fold) secretion. Gene expression of GIP was also increased (6.2- to 12.3-fold). Purified compounds from the ethyl acetate extract were identified as quinovic acid and its derivatives, $3 \beta-0-\beta$ D-glycopyranoside and $3 \beta$-O- $\beta$-D-glucopyranosyl-( $28 \rightarrow 1)-\beta$-Dglucopyranosyl ester ( $\bullet$ Fig. 2 ). These three compounds significantly stimulated GLP-1 secretion in $\mathrm{PGIP} /$ neo STC- 1 cells without triggering GIP secretion, but $3 \beta$-O- $\beta$-D-glucopyranosyl-(28 $\rightarrow 1)$ $\beta$-D-glucopyranosyl ester was the most active as secretagogue (at $25 \mu \mathrm{M}$ it increased GIP secretion 1.6-fold; at $50 \mu \mathrm{M}$ it increased the GLP-1 secretory response by 16.9-fold).
Other derivatives with potential as GLP-1 secretagogues are marnieranosides A and B ( $\vee$ Fig. 4), isolated from Cynanchum marnierianum Rauh (Apocynaceae). These pregnanes $(100 \mu \mathrm{M})$ increased the release of GLP-1 in STC-1 cells by 130 and $133 \%$, respectively. Isolated marnieranosides showed similar effects as compound P57, a pregnane analogue responsible for the activity of Hoodia gordonii (Masson) Sweet ex Decne. (Apocynaceae), used as a positive control [85]. These same authors isolated five new pregnane-type steroidal glycosides, menarandrosides A-E, together with three known compounds, from the aerial parts of Cynanchum menarandrense Jum. \& H.Perrier (Apocynaceae) and studied them for their potential to stimulate GLP-1 secretion in intestinal STC-1 cells. Although the pregnane-rich fraction led to a 2-fold stimulation of GLP-1 secretion vs. blank cells, none of the pure compounds had any influence, and the fraction enriched in pregnanes exhibited a significant activity, suggesting a possible synergistic effect [86].

Spergularia marina (L.) Besser (Caryophyllaceae) is an edible plant and it is also used as a medicinal plant in Korea for the treatment of diabetes. To analyze this activity, a hydroethanolic extract $(100,200$, and $500 \mu \mathrm{g} / \mathrm{mL})$ was tested on GLP-1 release from enteroendocrine $\mathrm{NCl}-\mathrm{H} 716$ cells. Treatment of these cells with the extract increased GLP-1 secretion together with iCa ${ }^{2+}$ and CAMP levels in a dose-dependent manner. Transfection of cells with 
TGR5-specific small interference RNA inhibited all these effects, which demonstrated that S. marina-stimulated GLP-1 secretion involved TGR5 activation and is a possible candidate for antidiabetic purposes [87].

The roots of Gentiana scabra Bunge (Gentianaceae) are used in traditional Korean medicine for treatment of T2D, and its properties were associated with the intestinal bitter taste sensation, which stimulates GLP-1 secretion. The aqueous extract stimulated GLP-1 secretion in a dose-dependent manner on human enteroendocrine $\mathrm{NCl}-\mathrm{H} 716$ cells $\left(1-1000 \mu \mathrm{g} / \mathrm{mL}, \mathrm{EC}_{50}\right.$ of $113.3 \mu \mathrm{g} /$ $\mathrm{mL}$ ). In addition, treated Lepr $^{-1-}(d b / d b)$ mice (100 and $300 \mathrm{mg} /$ $\mathrm{kg}$ ) decreased glycemia due to the GLP-1 secretion. After chemical analysis, the authors hypothesized that loganic acid ( $\bullet$ Fig. 5) could be the responsible part of GLP-1 secretion [88].

One group of high interest as a source of antidiabetic compounds is procyanidins from grape seed (Vitis vinifera L., Vitaceae). Since cellular membrane depolarization is determinant for several nutrient-induced hormone secretions, González-Abuín et al. [89] employed an in vitro experimental approach to evaluate whether a procyanidin extract from grape-seeds modulates cellular membrane potential in intestinal endocrine cells (STC-1) and if these changes influence GLP-1 secretion. They observed that the grape extract induced opposite effects depending on the dose, depolarization at low concentrations $(0.05 \mathrm{mg} / \mathrm{L})$ and hyperpolarization at high concentrations $(50 \mathrm{mg} / \mathrm{L})$. The high concentration was effective in reducing GLP-1 secretion, even under nutrient-stimulated conditions [89].

The proanthocyanidins from grape seed also modulate several parameters involved in metabolic syndrome through changes in the microbiota and enterohormone secretion. Indeed, it was observed that the ratio of Firmicutes: Bacteroidetes was lower in the microbiota of rats treated with proanthocyanidins $(500 \mathrm{mg} / \mathrm{kg}$, $8 \mathrm{~d})$ versus the control, but the extract also increased plasma GLP-1. For this reason, these kinds of phenolics could be of interest as potential antidiabetics [90].

Other anthocyanins of interest are those present in blackcurrant (Ribes nigrum L., Grossulariaceae), which increases GLP-1 secretion in an enteroendocrine $L$ cell line (GLUTag cells). The authors administrated $5 \mathrm{mg}$ of fruits $/ \mathrm{kg}$, with a content of $1 \mathrm{mg}$ delphinidin 3-rutinoside/kg, and observed that the enriched extract significantly improved glucose tolerance by stimulating GLP-1 and insulin secretion, while GLP-1 secretion was stimulated by delphinidin 3-rutinoside ( $\vee$ Fig. 3 ), but not by its major degradation products, gallic acid and phlorogucinol aldehyde [91].

Black soybean [Glycine max (L.) Merr., Leguminosae] is a type of soybean with a black seed coat. Previous studies identified anthocyanins and procyanidins as the two main types of polyphenols and described their antidiabetic effects. Qiu et al. [92] demonstrated that the phenolic-enriched crude extract increased the concentrations of serum insulin and GLP-1 in streptozotocin-induced diabetic rats after 8 weeks of treatment. However, they did not identify any specific compound in the extract.

Chlorogenic acids are ubiquitous phenolic compounds present in different medicinal plants as well as food and beverages, such as coffee. These kind of phenolics are responsible for different pharmacological activities, including antidiabetic [64,65]. To demonstrate the mechanism of these isomers, Tunnicliffe et al.

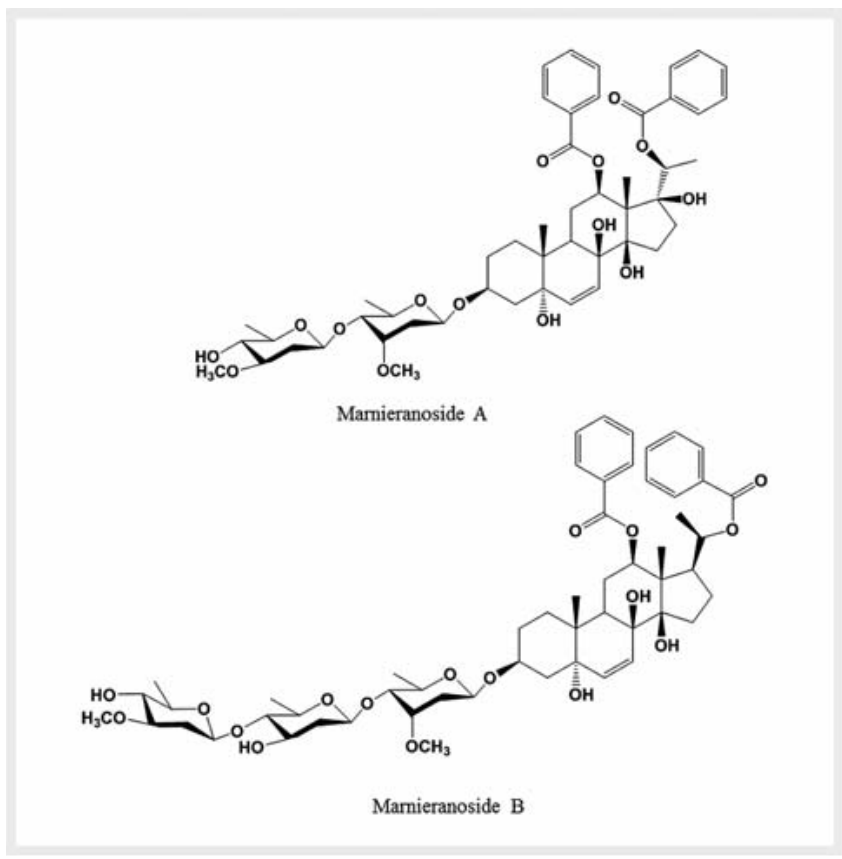

- Fig. 4 Chemical structure of marnieranosides A and B.

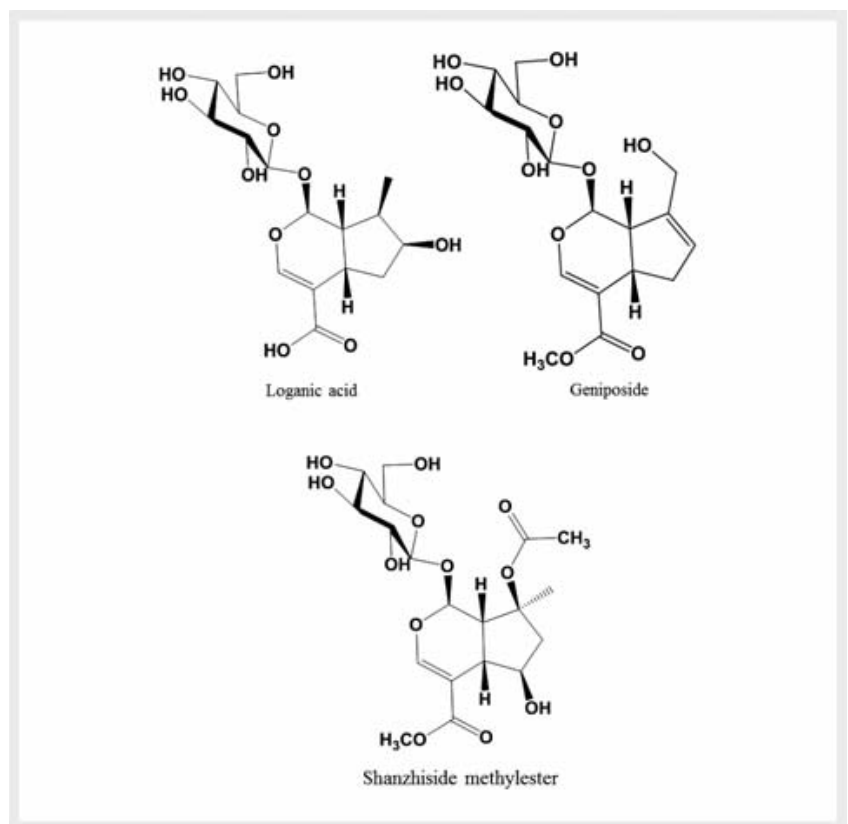

- Fig. 5 Chemical structures of loganic acid, geniposide, and shanzhiside methylester.

[93] administered $120 \mathrm{mg} / \mathrm{kg}$ of chlorogenic acids to male Sprague-Dawley rats and measured the incretins GLP-1 and GIP. GLP-1 response was also analyzed using the human colon cell line $\mathrm{NCl}-\mathrm{H} 716$. Results showed that the plasma GIP response was blunted in rats fed chlorogenic acids ( $\bullet$ Fig. $\mathbf{6}$ ), and there were no changes in GLP-1 secretion in vivo or in vitro, concluding that treatment with chlorogenic acids modifies GIP concentrations 


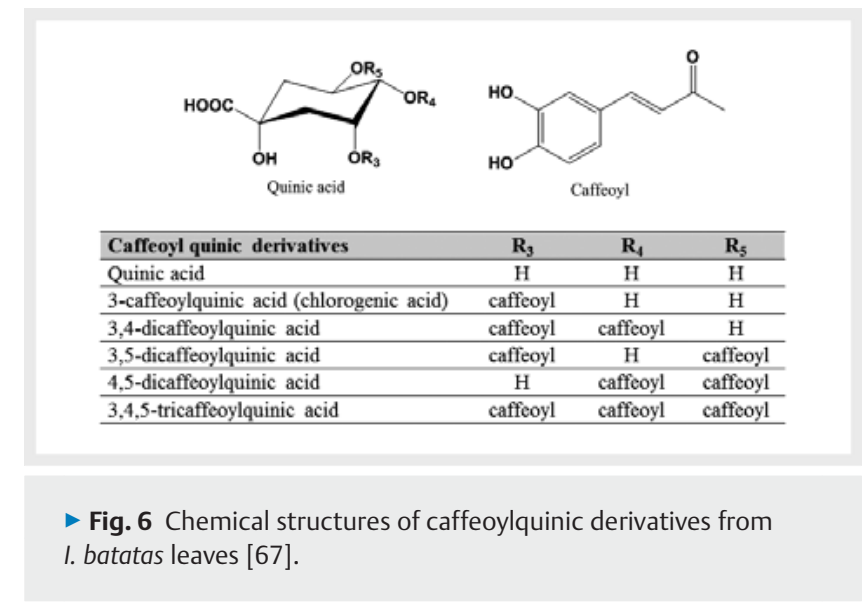

and reduces glycemia, justifying the potential antidiabetic effect of chlorogenic acids and coffee. Chlorogenic acids increase the production of GLP-1, and this incretin hormone acts on $\beta$-cells to promote the synthesis and activity of the transcription factor IDX1 , which is crucial for maintaining the responsiveness of $\beta$-cells to an increase in plasma glucose. In addition, chlorogenic acids have a putative impact on glucose absorption, and this delay may itself protect $\beta$-cells [65]. As mentioned above, the principal compounds studied in this chemical group were 3-caffeoylquinic acid, 3,4-dicaffeoylquinic acid, 3,5-dicaffeoylquinic acid, 4,5-dicaffeoylquinic acid, and 3,4,5-tricaffeoylquinic acid ( Fig. 6) [67].

Previous papers described Salvia fruticosa Mill. (Lamiaceae) as a possible source of antidiabetic compounds [94]. Azevedo et al. [95] studied more recently the effects of an infusion from this species (2.8 mg dry extract per $\mathrm{mL}$, “ad libitum") and its principal constituent rosmarinic acid ( $\triangleright$ Fig. 7) in drinking water $(577 \mu \mathrm{g} /$ $\mathrm{mL}$ ) "ad libitum". They studied different effects, including those on GLP-1 using streptozotocin-treated rats. Although the plasmatic levels of GLP-1 and the number of GLP-1-expressing cells per $\mathrm{cm}$ of villus was smaller in diabetic animals compared with healthy controls, none of the treatments caused any changes.

The effect of berberine ( $\bullet$ Fig. 7 ) on glucose metabolism in diabetic rats was studied by Zhang et al. [96], who used two doses of the compound (120 and $240 \mathrm{mg} / \mathrm{kg}$, during 8 weeks) and found that it significantly decreased fasting blood glucose levels and, in parallel, increased plasma postprandial GLP-1 levels. In addition, they verified that the GLP-1 receptor was significantly upregulated, suggesting that berberine can improve blood glucose levels in diabetic rats through a mechanism in which GLP-1 is implicated.

Puerarin ( $\triangleright$ Fig. 7) is a common isoflavone present in different vegetables, including medicinal plants such as Pueraria montana var. lobata (Willd.) Sanjappa \& Pradeep [syn: Pueraria lobata (Willd.) Ohwi, Leguminosae]. This compound was evaluated by Yang et al. [97] for its possible effects on $\beta$-cell survival, and the GLP-1R pathway in $d b / d b$ diabetic mice and isolated mouse islets treated with high glucose. They observed that the circulating level of GLP-1 in mice was unaffected, but puerarin enhanced GLP-1R expression. The protective effect of puerarin was suppressed by an antagonist of GLP-1R, concluding that puerarin protects $\beta$-cell

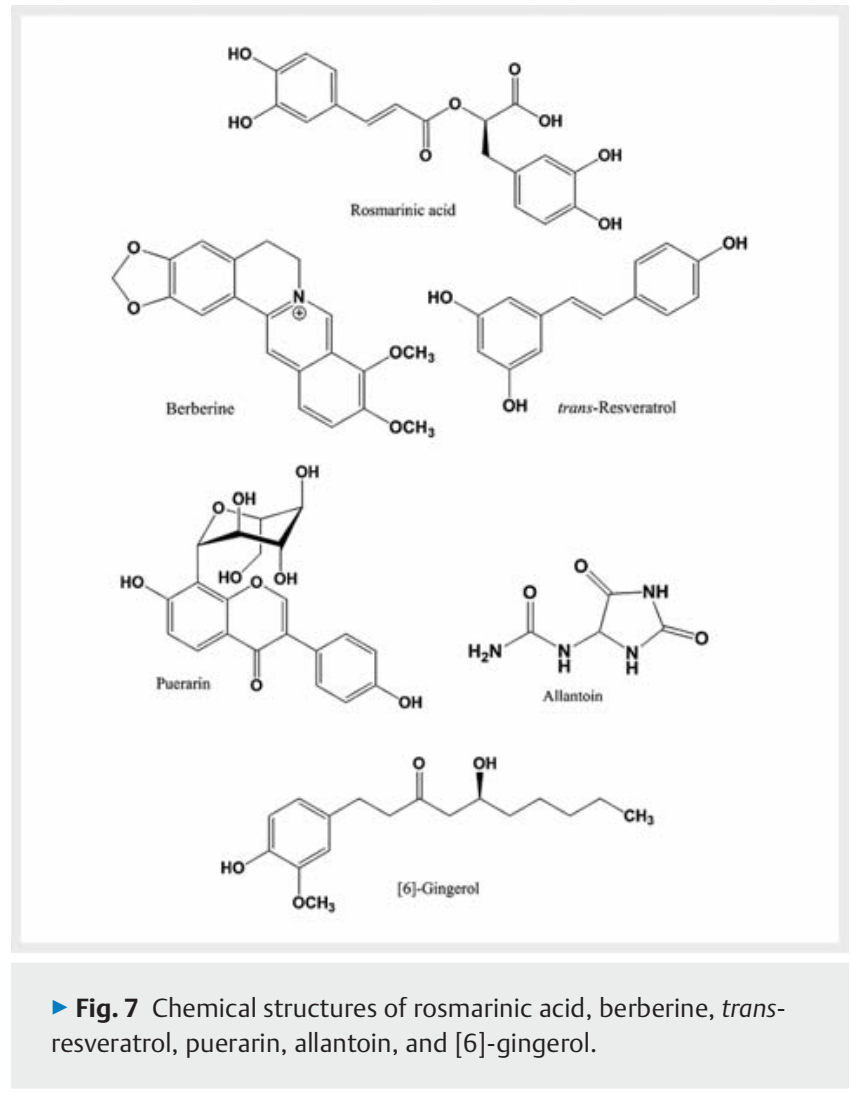

survival by mechanisms that involve the activation of GLP-1R signaling and downstream targets.

Different positive effects of iridoid geniposide ( $\bullet$ Fig. 5 ) on insulin secretion and glucose concentration were reported by Guo et al. [98]. In their experiments with rat INS-1 cells, geniposide $(0.01-100 \mu \mathrm{M})$ increased insulin secretion in a concentration-dependent manner, and at $10 \mu \mathrm{M}$, it enhanced acute insulin secretion in response to both low and moderately high levels of glucose. The blockade of GLP-1R with an antagonist (exendin, $200 \mathrm{nM}$ ) or the knock-down of GLP-1R with shRNA interference in cells decreased the effect of geniposide $(10 \mu \mathrm{M})$ on insulin secretion stimulated by glucose $(5.5 \mathrm{mmol} / \mathrm{L})$. Therefore, the authors concluded that geniposide increases insulin secretion through GLP-1 receptors in rat INS-1 insulinoma cells.

Shanzhiside methylester ( $\bullet$ Fig. 5) is an iridoid present in Phlomoides rotata (Benth. ex Hook.f.) Mathiesen [Syn: Lamiophlomis rotata (Benth. ex Hook.f.) Kudô, Lamiaceae]. The anti-allodynia effect of this monoterpene-glycoside is abolished by the selective GLP-1 receptor antagonist exendin (9-39). This fact made the authors consider this iridoid as a receptor agonist, however, it was not studied as a potential antidiabetic compound. Since it is a geniposide analogue, shanzhiside methylester could have similar effects on insulin secretion [99].

Crude powder of yam (Dioscorea polystachya Turcz., syn: Dioscorea batatas Decne., Discoreaceae), its water extract, and its active constituent allantoin ( $\bullet$ Fig. 7 ) were analyzed in a rat model of streptozotocin-induced diabetes. All of them produced a significant increase in GLP-1, with allantoin inducing an increment of $162 \%$ ( $2 \mathrm{mg} / \mathrm{kg}$, i.v.). The results indicate that yam and allantoin 
have antidiabetic effects through the modulation of antioxidant mechanisms and by promoting the release of GLP-1, thereby improving $\beta$-cell function, and maintaining normal insulin and glucose levels [100].

Hu et al. [101] studied the effects of ginger (Zingiber officinale Roscoe, Zingiberaceae) on gastric motility and emptying, abdominal symptoms, and hormones that influence motility in dyspepsia, including GLP-1 values, and they observed that the serum concentration of this incretin was modified. In the same line, Samad et al. [102] recently reported that GLP-1 mediates the insulinotropic activity of [6]-gingerol ( $\bullet$ Fig. 7), the major component of ginger. Treatment of $L e p r^{d b / d b}$ type 2 diabetic mice with this compound increased the activity of glycogen synthase 1 and enhanced the cell surface presentation of GLUT-4, facilitating glucose disposal in skeletal muscles.

- Table 3 compiles the principal compounds from medicinal plants and their effects on GLP-1 and GIP secretion. It includes active compounds, medicinal plants, concentration, experimental protocols and their effects.

\section{Clinical Trials}

The number of clinical trials focusing on the effects of medicinal plant extracts or natural products is quite scarce, and demonstrated limited effects. Andersson et al. [103] tested an extract (40 g for 6 weeks) of rose hip fruit (Rosa canina L., Rosaceae) in a randomized, double-blind, crossover study with a total of 31 obese individuals with normal or impaired glucose tolerance, but the extract had no effect on incretins.

Although Vallianou et al. [104] cited the antidiabetic potential of trans-resveratrol ( $\bullet$ Fig. 7), clinical trials conducted by Brasnyó et al. [105] did not associate this property with incretins. Indeed, in a study with 19 patients with T2D, only small changes were detected between the groups treated with resveratrol $(5 \mathrm{mg} \times$ each day during 4 weeks) versus placebo, but they were not significant. However, these results must be taken with caution due to the small number of patients employed.

More promising results were found by Törrönen et al. [106], who evaluated the effects of different berries on postprandial glucose, insulin, and GLP-1 responses, comparing them with a similar sucrose load without berries. The study was a randomized, singleblinded, placebo-controlled, crossover study and enrolled 12 healthy subjects. The participants had two meals on separate days based on $150 \mathrm{~g}$ of a puree made with bilberries (Vaccinium myrtillus L., Ericaceae), cranberries (Vaccinium macrocarpon Aiton), blackcurrants (Ribes nigrum), and strawberries [Fragaria $\times$ ananassa (Duchesne ex Weston) Duchesne ex Rozier, Rosaceae] and $35 \mathrm{~g}$ of added sucrose (placebo group received an equivalent dose of sucrose). The glycemia, insulinemia, and GLP-1 concentrations were monitored during 15 to 120 min after taking the meal. Glucose and insulin concentrations were reduced in the group taking the berry-based meal, although only a modest effect on the GLP-1 response $(p=0.05)$ was observed.

Regarding worldwide consumed stimulating beverages, such as coffee and tea, two interesting clinical trials were performed. Johnston et al. [64] carried out a randomized, crossover study with 9 healthy fasted volunteers who were given $25 \mathrm{~g}$ of glucose in either $400 \mathrm{~mL}$ of water (control) or $400 \mathrm{~mL}$ of caffeinated or decaffeinated coffee (equivalent to $2.5 \mathrm{mM}$ chlorogenic acid). GIP secretion decreased, whereas GLP-1 secretion increased (0120 min, postprandial) after decaffeinated coffee consumption compared with the control and caffeinated coffee. These results confirmed the known metabolic effects of caffeine. The gastrointestinal hormonal profiles were consistent with delayed intestinal glucose absorption, suggesting that chlorogenic acid might have an antagonistic effect on glucose transport, attenuating intestinal glucose absorption and shifting its absorption to more distal parts of the intestine. Green tea (Camellia sinensis), which has a similar phenolic compound profile, was also tested in another clinical trial with 92 patients with T2D. Thirty-nine of them drank $500 \mathrm{mg}$ of green tea extract, three times a day. After 16 weeks, the green tea extract caused a significant increase in GLP-1 versus placebo and significantly improved insulin resistance [107].

More recently, Castro-Acosta et al. [108] published the results of a randomized, controlled, double-blinded, crossover trial conducted in healthy volunteers to investigate if enriched polyphenol drinks based on apple [Malus sylvestris (L.) Mill., Rosaceae] and blackcurrant (Ribes nigrum L.) could affect postprandial blood glucose concentrations. They analyzed different parameters, including GIP secretion, in 20 men (age average: 26 years old) and 5 postmenopausal women (age average: 57 years old) who consumed two polyphenol-rich drinks containing fruit extracts or placebo. Doses administered were $1200 \mathrm{mg}$ of apple polyphenols, or apple polyphenols $(600 \mathrm{mg})+$ blackcurrant anthocyanins (600 mg). Postprandial insulin and GIP concentrations were significantly reduced compared to placebo, but postprandial glycemia decreased, probably due to the inhibition of GLUT-2 and SGLT1mediated intestinal glucose transport.

Finally, in this last year, two clinical trials dealing with dietary supplements have been published. Boix-Castejón et al. [109] analyzed a dietary supplement based on a combination of two phenolic extracts from Aloysia citriodora Palau [syn: Lippia citriodora (Palau) Kunth, Verbenaceae] and Hibiscus sabdariffa L. (Malvaceae). They studied 54 overweight subjects in a double-blind, placebo-controlled intervention, monitoring different vital parameters during 60 days. Patients taking the phenolic extracts had an increase in anorexigenic hormones (GLP-1), whereas the orexigenic hormones (ghrelin) decreased. Zanzer et al. [110] evaluated the effect of a black pepper-based (Piper nigrum L., Piperaceae) beverage containing gallic acid equivalent $(20 \mathrm{mg})$ in a randomized, crossover intervention in 16 healthy subjects (10 men and 6 women, average age: 26 years old). In this case, they only noticed some evidence in appetite modulation, but they did not observe changes in glycemia or gut hormone levels (including GLP-1).

\section{Future Perspectives and Conclusions}

Although this review shows several compounds of interest for the treatment of T2D that modify glycemia via the modulation of incretin activity, either by direct activation or by repression of its inhibitor, there is not a clear structural relationship among them. The terpenic derivatives of ursane-type structure stand out, with the glycosylated bidesmosidic derivative being the most active 
- Table 3 Natural products as stimulants of GLP-1 and GIP secretion.

\begin{tabular}{|c|c|c|c|c|c|}
\hline Compound & Plant & Concentration & Protocol & Effects & Ref \\
\hline Allantoin & Dioscorea polystachya & $2 \mathrm{mg} / \mathrm{kg}$, i.v. & $\begin{array}{l}\text { STZ-treated Sprague- } \\
\text { Dawley rats }\end{array}$ & Increases release of GLP-1 & {$[100]$} \\
\hline Berberine & Coptis chinensis & 120 and $240 \mathrm{mg} / \mathrm{kg}$ & $\begin{array}{l}\text { STZ-treated Sprague- } \\
\text { Dawley rats }\end{array}$ & Increases GLP-1 levels & [96] \\
\hline Chlorogenic acids & Coffea arabica & $120 \mathrm{mg} / \mathrm{kg}$ & $\begin{array}{l}\text { Sprague-Dawley rats } \\
\mathrm{NCl}-\mathrm{H} 716 \text { cells }\end{array}$ & $\begin{array}{l}\text { Increases GIP concentra- } \\
\text { tions and GLP-1 produc- } \\
\text { tion }\end{array}$ & [93] \\
\hline $\begin{array}{l}\text { Cyanidin } \\
\text { 3,5-diglucoside }\end{array}$ & Aronia sp. & $\mathrm{IC}_{50}$ of $5.5 \mu \mathrm{M}$ & $\begin{array}{l}\text { In vitro } \\
\text { DPP-4 + Gly-Pro-MCA }\end{array}$ & $\begin{array}{l}\text { DPP- } 4 \text { inhibition and } \\
\text { increases GLP-1 and GIP } \\
\text { levels }\end{array}$ & {$[83]$} \\
\hline $\begin{array}{l}\text { Delphinidin } \\
\text { 3-rutinoside }\end{array}$ & Ribes nigrum & $\begin{array}{l}\text { Fruits } 5 \mathrm{mg} / \mathrm{kg} \\
\text { with } 1 \mathrm{mg} / \mathrm{kg} \text { delphini- } \\
\text { din 3-rutinoside }\end{array}$ & GLUTag cells & $\begin{array}{l}\text { Stimulates GLP-1 and } \\
\text { insulin secretion }\end{array}$ & [91] \\
\hline Geniposide & Gardenia jasminoides & $10 \mu \mathrm{M}$ & INS- 1 cells & $\begin{array}{l}\text { Increases insulin secre- } \\
\text { tion through GLP-1 }\end{array}$ & [98] \\
\hline [6]-Gingerol & Zingiber officinale & $200 \mathrm{mg} / \mathrm{kg}$ & Lepr ${ }^{\mathrm{db} / d b}$ diabetic mice & $\begin{array}{l}\text { Activates GLP-1-mediat- } \\
\text { ed insulin secretion }\end{array}$ & [102] \\
\hline Marnieranoside A & $\begin{array}{l}\text { Cynanchum } \\
\text { marnierianum }\end{array}$ & $100 \mu \mathrm{M}$ & STC -1 cells & $\begin{array}{l}\text { Increases release of GLP-1 } \\
\text { by } 130 \%\end{array}$ & [86] \\
\hline Marnieranoside B & $\begin{array}{l}\text { Cynanchum } \\
\text { marnierianum }\end{array}$ & $100 \mu \mathrm{M}$ & STC -1 cells & $\begin{array}{l}\text { Increases release of GLP-1 } \\
\text { by } 133 \%\end{array}$ & [86] \\
\hline Procyanidins & Vitis vinifera & 0.05 and $50 \mathrm{mg} / \mathrm{L}$ & STC -1 cells & $\begin{array}{l}\text { Suppression of GLP-1 } \\
\text { secretion! }\end{array}$ & [89] \\
\hline Procyanidins & Vitis vinifera & $500 \mathrm{mg} / \mathrm{kg}$ & Wistar rats & Increases plasma GLP-1 & {$[90]$} \\
\hline Puerarin & $\begin{array}{l}\text { Pueraria montana } \\
\text { var. lobata }\end{array}$ & 150 and $300 \mathrm{mg} / \mathrm{kg}$ & $d b / d b$ diabetic mice & $\begin{array}{l}\text { Enhances GLP-1R } \\
\text { expression }\end{array}$ & [97] \\
\hline $\begin{array}{l}\text { Quinovic acid-3 } \beta \text {-O- } \\
\beta \text {-D-glucopyranosyl- } \\
(28 \rightarrow 1)-\beta \text {-D-gluco- } \\
\text { pyranosyl ester }\end{array}$ & Fagonia cretica & $25 \mu \mathrm{M}$ and $50 \mu \mathrm{M}$ & $\begin{array}{l}\text { pGIP/neo STC-1 cells } \\
\text { GLP-1 and GIP ELISA } \\
\text { kits }\end{array}$ & $\begin{array}{l}\text { Increases GIP secretion } \\
1.6 \text {-fold }(25 \mu \mathrm{M}) \\
\text { Increases GLP-1 secretion } \\
\text { 16.9-fold }(50 \mu \mathrm{M})\end{array}$ & {$[84]$} \\
\hline Rosmarinic acid & Salvia fruticosa & $\begin{array}{l}577 \mu \mathrm{g} / \mathrm{mL} \text {, in water } \\
\text { "ad libitum" }\end{array}$ & STZ-treated Wistar rats & No changes in GLP-1 & [95] \\
\hline $\begin{array}{l}\text { Shanzhiside } \\
\text { methylester }\end{array}$ & Phlomoides rotata & $\begin{array}{l}10,30,100, \text { and } \\
300 \mu \mathrm{g} \text { intrathecal }\end{array}$ & $\begin{array}{l}\text { Wistar rats, } \\
\text { allodynia test }\end{array}$ & GLP-1 receptor agonist & [99] \\
\hline
\end{tabular}

(IC 50 of $23.5 \mu \mathrm{M}$ ) as an inhibitor of the DPP-4 enzyme; among the phenolic derivatives, cyanidin 3,5-diglucoside, with an $\mathrm{IC}_{50}$ of $5.5 \mu \mathrm{M}$, stands out. Considering the compounds that stimulate GLP-1 secretion, triterpenic derivatives are likewise worth mentioning, since they are also bidesmosidic derivatives and marnieranosides pregnane derivatives, especially with compounds $A$ and $\mathrm{B}$ (bi- and triglycoside, respectively) being the most active. Even more interesting are the iridoids (monoterpene-glucosides), such as geniposide and shanzhiside methylester, which act as GLP-1 receptor agonists. Other compounds, such as caffeoylquinic acid derivatives, rosmarinic acid, trans-resveratrol, puerarin, and the alkaloid berberine, could also be of interest.

Among the results obtained experimentally as well as the previous data referred to in food or clinical trials, it is reasonable to hypothesize that the inhibition of DPP-4 could be a valid alternative to deepen these type of studies. However, the limited number of clinical trials and the small number of patients means that definitive conclusions cannot be drawn for these compounds. Therefore, it is recommended to increase the number of trials, putting emphasis on the importance of unifying the protocols, as well as increasing the number of patients to follow. Regarding the tests with experimental animals, it is worth highlighting some compounds whose mechanism is related to the activation of GLP-1R, especially the iridoid derivatives, which could be valid as leads for a series of studies with structural analogues. Derivatives of cyanidin, especially diglycosylated ones, may also be valid, since they can be an interesting source of DPP-4 inhibitory molecules and therefore indirectly give rise to the active form of incretins.

In view of the small number of clinical trials, it is only possible to postulate the complementary use of these medicinal plants and their active compounds together with standard drugs (e.g., metformin) in the treatment of patients diagnosed with T2D or 
in prediabetes phases. In cases of foods studied as potential antidiabetics via incretins, no clear results have been obtained, with only those which, in practice, can be considered active substances of medicinal plants being effective, such as guar gum or phenolic derivatives from different sources. In conclusion, the use of medicinal plants or active compounds should be considered only as complementary therapy and not as a substitution treatment. On the other hand, there are some active principles that could be investigated as potential leads for future treatments of T2D.

\section{Acknowledgements}

The authors thank Brian Normanly for his English language editing.

Conflict of Interest

The authors declare no conflicts of interest.

References

[1] Holst JJ. Glucagon-like Peptide 1 (GLP-1): An Intestinal Hormone, Signalling Nutritional Abundance, with an Unusual Therapeutic Potential. Trends Endocrinol Metab 1999; 10: 229-235

[2] Drucker DJ. The role of gut hormones in glucose homeostasis. J Clin Invest 2007; 117: 24-32

[3] Deacon CF, Ahrén B. Physiology of incretins in health and disease. Rev Diabet Stud 2011; 8: 293-306

[4] Nauck MA, Meier JJ. Incretin hormones: Their role in health and disease. Diabetes Obes Metab 2018; 20 (Suppl. 1): 5-21

[5] Sun EWL, Martin AM, Young RL, Keating D]. The regulation of peripheral metabolism by gut-derived hormones. Front Endocrinol 2019; 9: 754

[6] Drucker DJ, Nauck MA. The incretin system: glucagon-like peptide-1 receptor agonists and dipeptidyl peptidase-4 inhibitors in type 2 diabetes. Lancet 2006; 368: 1696-1705

[7] Sun L, Wang C, Dai Y, Chu Y, Han J, Zhou J, Cai X, Huang W, Qian H. Coumaglutide, a novel long-acting GLP-1 analog, inhibits $\beta$-cell apoptosis in vitro and invokes sustained glycemic control in vivo. Eur ] Pharmacol 2015; 7767: 211-219

[8] Sharma D, Verma S, Vaidya S, Kalia K, Tiwari V. Recent updates on GLP-1 agonists: current advancements and challenges. Biomed Pharmacother 2018; 108: 952-962

[9] Nauck M, Stöckmann F, Ebert R, Creutzfeldt W. Reduced incretin effect in type 2 (non-insulin-dependent) diabetes. Diabetologia 1986; 29: 4652

[10] Meier J], Nauck MA. Is the diminished incretin effect in type 2 diabetes just an epi-phenomenon of impaired beta-cell function? Diabetes 2010; 59: $1117-1125$

[11] Holst J], Knop FK, Vilsbøll T, Krarup T, Madsbad S. Loss of incretin effect is a specific, important, and early characteristic of type 2 diabetes. Diabetes Care 2011; 34 (Suppl. 2): S251-S257

[12] Turton MD, O'Shea D, Gunn I, Beak SA, Edwards CM, Meeran K, Choi S], Taylor GM, Heath MM, Lambert PD, Wilding JP, Smith DM, Ghatei MA, Herbert J, Bloom SR. A role for glucagon-like peptide- 1 in the central regulation of feeding. Nature 1996; 379: 69-72

[13] Schirra J, Nicolaus M, Roggel R, Katschinski M, Storr M, Woerle H], Göke B. Endogenous glucagon-like peptide 1 controls endocrine pancreatic secretion and antro-pyloro-duodenal motility in humans. Gut 2006; 55 : 243-251

[14] Baggio LL, Drucker DJ. Biology of incretins: GLP-1 and GIP. Gastroenterology 2007; 132: 2131-2157
[15] Wang Z, Wang RM, Owji AA, Smith DM, Ghatei MA, Bloom SR. Glucagon-like peptide-1 is a physiological incretin in rat. J Clin Invest 1995; 95: 417-421

[16] Drucker D]. The biology of incretin hormones. Cell Metab 2006; 3: $153-$ 165

[17] Ritzel R, Orskov C, Holst J], Nauck MA. Pharmacokinetic, insulinotropic, and glucagonostatic properties of GLP-1 [7-36 amide] after subcutaneous injection in healthy volunteers. Dose-response-relationships. Diabetologia 1995; 38: 720-725

[18] Holst J], Christensen M, Lund A, de Heer J, Svendsen B, Kielgast U, Knop FK. Regulation of glucagon secretion by incretins. Diabetes Obes Metab 2011; 13 (Suppl. 1): 89-94

[19] Preitner F, Ibberson M, Franklin I, Binnert C, Pende M, Gjinovci A, Hansotia T, Drucker DJ, Wollheim C, Burcelin R, Thorens B. Gluco-incretins control insulin secretion at multiple levels as revealed in mice lacking GLP-1 and GIP receptors. J Clin Invest 2004; 113: 635-645

[20] Burcelin R, Da Costa A, Drucker D, Thorens B. Glucose competence of the hepatoportal vein sensor requires the presence of an activated glucagon-like peptide-1 receptor. Diabetes 2001; 50: 1720-1728

[21] Gupta NA, Mells J, Dunham RM, Grakoui A, Handy J, Saxena NK, Anania FA. Glucagon-like peptide-1 receptor is present on human hepatocytes and has a direct role in decreasing hepatic steatosis in vitro by modulating elements of the insulin signaling pathway. Hepatology 2010; 51: 1584-1592

[22] Svegliati-Baroni G, Saccomanno S, Rychlicki C, Agostinelli L, De Minicis S, Candelaresi C, Faraci G, Pacetti D, Vivarelli M, Nicolini D, Garelli P, Casini A, Manco M, Mingrone G, Risaliti A, Frega GN, Benedetti A, Gastaldelli A. Glucagon-like peptide-1 receptor activation stimulates hepatic lipid oxidation and restores hepatic signalling alteration induced by a high-fat diet in nonalcoholic steatohepatitis. Liver Int 2011; 31: 1285-1297

[23] Ding X, Saxena NK, Lin S, Gupta NA, Anania FA. Exendin-4, a glucagonlike protein-1 (GLP-1) receptor agonist, reverses hepatic steatosis in ob/ ob mice. Hepatology 2006; 43: 173-181

[24] Mells JE, Fu PP, Sharma S, Olson D, Cheng L, Handy JA, Saxena NK, Sorescu D, Anania FA. GLP-1 analog, liraglutide, ameliorates hepatic steatosis and cardiac hypertrophy in C57BL/6 J mice fed a Western diet. Am J Physiol Gastrointest Liver Physiol 2012; 302: G225-G235

[25] Ben-Shlomo S, Zvibel I, Shnell M, Shlomai A, Chepurko E, Halpern Z, Barzilai N, Oren R, Fishman S. Glucagon-like peptide-1 reduces hepatic lipogenesis via activation of AMP-activated protein kinase. J Hepatol 2011; 54: 1214-1223

[26] Tomas E, Stanojevic V, Habener JF. GLP-1 (9-36) amide metabolite suppression of glucose production in isolated mouse hepatocytes. Horm Metab Res 2010; 42: 657-662

[27] Tomas E, Stanojevic V, Habener JF. GLP-1-derived nonapeptide GLP-1 (28-36)amide targets to mitochondria and suppresses glucose production and oxidative stress in isolated mouse hepatocytes. Regul Pept 2011; 167: 177-184

[28] Tomas E, Wood JA, Stanojevic V, Habener JF. Glucagon-like peptide-1(936)amide metabolite inhibits weight gain and attenuates diabetes and hepatic steatosis in diet-induced obese mice. Diabetes Obes Metab 2011; 13: 26-33

[29] Ceriello A, Esposito K, Testa R, Bonfigli AR, Marra M, Giugliano D. The possible protective role of glucagon-like peptide 1 on endothelium during the meal and evidence for an "endothelial resistance" to glucagonlike peptide 1 in diabetes. Diabetes Care 2011; 34: 697-702

[30] Oeseburg H, de Boer RA, Buikema H, van der Harst P, van Gilst WH, Silljé $\mathrm{HH}$. Glucagon-like peptide 1 prevents reactive oxygen species-induced endothelial cell senescence through the activation of protein kinase $A$. Arterioscler Thromb Vasc Biol 2010; 30: 1407-1414

[31] Holst J], Deacon CF. Glucagon-like peptide 1 and inhibitors of dipeptidyl peptidase IV in the treatment of type 2 diabetes mellitus. Curr Opin Pharmacol 2004; 4: 589-596 
[32] Nauck MA, Vardarli I, Deacon CF, Holst J], Meier J]. Secretion of glucagonlike peptide-1 (GLP-1) in type 2 diabetes: what is up, what is down? Diabetologia 2011; 54: 10-18

[33] Meneses M], Silva BM, Sousa M, Sá R, Oliveira PF, Alves MG. Antidiabetic drugs: mechanisms of action and potential outcomes on cellular metabolism. Curr Pharm Des 2015; 21: 3606-3620

[34] Ríos JL, Francini F, Schinella GR. Natural products for the treatment of type 2 diabetes mellitus. Planta Med 2015; 81: 975-994

[35] Inzucchi SE, Bergenstal RM, Buse JB, Diamant M, Ferrannini E, Nauck M, Peters AL, Tsapas A, Wender R, Matthews DR. Management of hyperglycemia in type 2 diabetes, 2015: a patient-centered approach: update to a position statement of the American Diabetes Association and the European Association for the Study of Diabetes. Diabetes Care 2015; 38: 140-149

[36] Irons BK, Minze MG. Drug treatment of type 2 diabetes mellitus in patients for whom metformin is contraindicated. Diabetes Metab Syndr Obes 2014; 7: 15-24

[37] Guja C, Frías JP, Somogyi A, Jabbour S, Wang H, Hardy E, Rosenstock J. Effect of exenatide QW or placebo, both added to titrated insulin glargine, in uncontrolled type 2 diabetes: The DURATION-7 randomized study. Diabetes Obes Metab 2018; 20: 1602-1614

[38] Henry RR, Rosenstock J, Denham DS, Prabhakar P, Kjems L, Baron MA. Clinical impact of ITCA 650, a novel drug-device GLP-1 receptor agonist, in uncontrolled type 2 diabetes and very high baseline HbA1c: The FREEDOM-1 HBL (High Baseline) study. Diabetes Care 2018; 41: 613619

[39] Nielsen LL, Young AA, Parkes DG. Pharmacology of exenatide (synthetic exendin-4): a potential therapeutic for improved glycemic control of type 2 diabetes. Regul Pept 2004; 117: 77-88

[40] Amori RE, Lau J, Pittas AG. Efficacy and safety of incretin therapy in type 2 diabetes: systematic review and meta-analysis. JAMA 2007; 298: 194206

[41] Kang YM, Cho YK, Lee J, Lee SE, Lee WJ, Park JY, Kim YJ, Jung CH, Nauck MA. Asian subpopulations may exhibit greater cardiovascular benefit from long-acting glucagon-like peptide 1 receptor agonists: A metaanalysis of cardiovascular outcome trials. Diabetes Metab J 2018; 42: e51

[42] Andrikou E, Tsioufis C, Andrikou I, Leontsinis I, Tousoulis D, Papanas N. GLP-1 receptor agonists and cardiovascular outcome trials: An update. Hellenic J Cardiol 2018. doi:10.1016/j.hjc.2018.11.008

[43] Grouzmann E, Monod M, Landis BN, Lacroix JS. Adverse effects of incretin therapy for type 2 diabetes. JAMA 2007; 298: 1759-1760

[44] Filippatos TD, Panagiotopoulou TV, Elisaf MS. Adverse effects of GLP-1 receptor agonists. Rev Diabet Stud 2014; 11: 202-230

[45] Wang T, Wang F, Zhou J, Tang H, Giovenale S. Adverse effects of incretinbased therapies on major cardiovascular and arrhythmia events: metaanalysis of randomized trials. Diabetes Metab Res Rev 2016; 32: 843857

[46] Willard FS, Bueno AB, Sloop KW. Small molecule drug discovery at the glucagon-like peptide-1 receptor. Exp Diabetes Res 2012; 2012: 709893

[47] Thompson A, Stephens JW, Bain SC, Kanamarlapudi V. Molecular characterisation of small molecule agonists effect on the human glucagon like peptide-1 receptor internalisation. PLoS One 2016; 11: e0154229

[48] Thomsen C, Rasmussen O, Lousen T, Holst J], Fenselau S, Schrezenmeir J, Hermansen K. Differential effects of saturated and monounsaturated fatty acids on postprandial lipemia and incretin responses in healthy subjects. Am J Clin Nutr 1999; 69: 1135-1143

[49] Thomsen C, Storm H, Holst J, Hermansen K. Differential effects of saturated and monounsaturated fats on postprandial lipemia and glucagonlike peptide 1 responses in patients with type 2 diabetes. Am J Clin Nutr 2003; 77: 605-611

[50] Iritani N, Sugimoto T, Fukuda H, Komiya M, Ikeda H. Oral triacylglycerols regulate plasma glucagon-like peptide-1(7-36) and insulin levels in normal and especially in obese rats. J Nutr 1999; 129: 46-50
[51] Prieto PG, Cancelas ], Villanueva-Peñacarrillo ML, Valverde I, Malaisse W]. Effects of an olive oil-enriched diet on plasma GLP-1 concentration and intestinal content, plasma insulin concentration, and glucose tolerance in normal rats. Endocrine 2005; 26: 107-115

[52] Cancelas ], Prieto PG, Villanueva-Peñacarrillo ML, Valverde I, Malaisse W]. Effects of an olive oil-enriched diet on glucagon-like peptide 1 release and intestinal content, plasma insulin concentration, glucose tolerance and pancreatic insulin content in an animal model of type 2 diabetes. Horm Metab Res 2006; 38: 98-105

[53] D’Alessio D, Lu W, Sun W, Zheng S, Yang Q, Seeley R, Woods SC, Tso P. Fasting and postprandial concentrations of glucagon-like peptide 1 in intestinal lymph and portal plasma: evidence for selective release of GLP-1 into the lymph system. Am J Physiol Regul Integr Comp Physiol 2007; 293: R2163-R2169

[54] Lu W], Yang Q, Sun W, Woods SC, D’Alessio D, Tso P. The regulation of the lymphatic secretion of glucagon-like peptide-1 (GLP-1) by intestinal absorption of fat and carbohydrate. Am J Physiol Gastrointest Liver Physiol 2007; 293: G963-G971

[55] Yoder SM, Yang Q, Kindel TL, Tso P. Stimulation of incretin secretion by dietary lipid: is it dose dependent? Am J Physiol Gastrointest Liver Physiol 2009; 297: G299-G305

[56] Cheshmehkani A, Senatorov IS, Kandi P, Singh M, Britt A, Hayslett R, Moniri NH. Fish oil and flax seed oil supplemented diets increase FFAR4 expression in the rat colon. Inflamm Res 2015; 64: 809-815

[57] Lindgren O, Carr RD, Deacon CF, Holst J], Pacini G, Mari A, Ahrén B. Incretin hormone and insulin responses to oral versus intravenous lipid administration in humans. J Clin Endocrinol Metab 2011; 96: 2519-2524

[58] Manning P], Sutherland WH, Manning AE, de Jong SA, Berry EA. Ingestion of thermally oxidized sunflower oil decreases postprandial lipemia mainly in younger individuals. Nutr Res 2013; 33: 711-718

[59] UI Kabir A, Samad MB, Ahmed A, Jahan MR, Akhter F, Tasnim J, Hasan SM, Sayfe SS, Hannan JM. Aqueous fraction of Beta vulgaris ameliorates hyperglycemia in diabetic mice due to enhanced glucose stimulated insulin secretion, mediated by acetylcholine and GLP-1, and elevated glucose uptake via increased membrane bound GLUT4 transporters. PLoS One 2015; 10: e0116546

[60] Ellis PR, Roberts FG, Low AG, Morgan LM. The effect of high-molecularweight guar gum on net apparent glucose absorption and net apparent insulin and gastric inhibitory polypeptide production in the growing pig: relationship to rheological changes in jejunal digesta. Br J Nutr 1995; 74 : 539-556

[61] Gatenby SJ, Ellis PR, Morgan LM, Judd PA. Effect of partially depolymerized guar gum on acute metabolic variables in patients with non-insulindependent diabetes. Diabet Med 1996; 13: 358-364

[62] den Besten G, Gerding A, van Dijk TH, Ciapaite J, Bleeker A, van Eunen K, Havinga R, Groen AK, Reijngoud DJ, Bakker BM. Protection against the metabolic syndrome by guar gum-derived short-chain fatty acids depends on peroxisome proliferator-activated receptor $\gamma$ and glucagon-like peptide-1. PLoS One 2015; 10: e0136364

[63] Karhunen LJ, Juvonen KR, Flander SM, Liukkonen KH, Lähteenmäki L, Siloaho M, Laaksonen DE, Herzig KH, Uusitupa MI, Poutanen KS. A psyllium fiber-enriched meal strongly attenuates postprandial gastrointestinal peptide release in healthy young adults. J Nutr 2010; 140: 737-744

[64] Johnston KL, Clifford MN, Morgan LM. Coffee acutely modifies gastrointestinal hormone secretion and glucose tolerance in humans: glycemic effects of chlorogenic acid and caffeine. Am J Clin Nutr 2003; 78: 728733

[65] McCarty MF. A chlorogenic acid-induced increase in GLP-1 production may mediate the impact of heavy coffee consumption on diabetes risk. Med Hypotheses 2005; 64: 848-853

[66] Esatbeyoglu T, Rodríguez-Werner M, Schlösser A, Liehr M, Ipharraguerre I, Winterhalter P, Rimbach G. Fractionation of plant bioactives from black carrots (Daucus carota subspecies sativus varietas atrorubens Alef.) by 
adsorptive membrane chromatography and analysis of their potential anti-diabetic activity. J Agric Food Chem 2016; 64: 5901-5908

[67] Nagamine R, Ueno S, Tsubata M, Yamaguchi K, Takagaki K, Hira T, Hara H, Tsuda T. Dietary sweet potato (Ipomoea batatas L.) leaf extract attenuates hyperglycaemia by enhancing the secretion of glucagon-like peptide-1 (GLP-1). Food Funct 2014; 5: 2309-2316

[68] Hung HY, Qian K, Morris-Natschke SL, Hsu CS, Lee KH. Recent discovery of plant-derived anti-diabetic natural products. Nat Prod Rep 2012; 29: 580-606

[69] Eddouks M, Bidi A, El Bouhali B, Hajji L, Zeggwagh NA. Antidiabetic plants improving insulin sensitivity. J Pharm Pharmacol 2014; 66: 11971214

[70] Ribnicky DM, Poulev A, Watford M, Cefalu WT, Raskin I. Antihyperglycemic activity of Tarralin, an ethanolic extract of Artemisia dracunculus L. Phytomedicine 2006; 13: 550-557

[71] Park S, Hong SM, Ahn IS, Kim YJ, Lee JB. Huang-Lian-Jie-Du-Tang supplemented with Schisandra chinensis Baill. and Polygonatum odoratum Druce improved glucose tolerance by potentiating insulinotropic actions in islets in 90\% pancreatectomized diabetic rats. Biosci Biotechnol Biochem 2009; 73: 2384-2392

[72] Hussein GM, Matsuda H, Nakamura S, Hamao M, Akiyama T, Tamura K, Yoshikawa M. Mate tea (Ilex paraguariensis) promotes satiety and body weight lowering in mice: involvement of glucagon-like peptide-1. Biol Pharm Bull 2011; 34: 1849-1855

[73] Kubow S, Hobson L, Iskandar MM, Sabally K, Donnelly DJ, Agellon LB. Extract of Irish potatoes (Solanum tuberosum L.) decreases body weight gain and adiposity and improves glucose control in the mouse model of diet-induced obesity. Mol Nutr Food Res 2014; 58: 2235-2238

[74] Raasmaja A, Lecklin A, Li XM, Zou J, Zhu GG, Laakso I, Hiltunen R. A water-alcohol extract of Citrus grandis whole fruits has beneficial metabolic effects in the obese Zucker rats fed with high fat/high cholesterol diet. Food Chem 2013; 138: 1392-1399

[75] Bhat GA, Khan HA, Alhomida AS, Sharma P, Singh R, Paray BA. GLP-I secretion in healthy and diabetic Wistar rats in response to aqueous extract of Momordica charantia. BMC Complement Altern Med 2018; 18: 162. Erratum in: BMC Complement Altern Med 2018; 18: 175 and BMC Complement Altern Med 2018; 18: 182

[76] Kosaraju ], Dubala A, Chinni S, Khatwal RB, Satish Kumar MN, Basavan D. A molecular connection of Pterocarpus marsupium, Eugenia jambolana and Gymnema sylvestre with dipeptidyl peptidase-4 in the treatment of diabetes. Pharm Biol 2014; 52: 268-271

[77] Kosaraju ], Madhunapantula SV, Chinni S, Khatwal RB, Dubala A, Muthureddy Nataraj SK, Basavan D. Dipeptidyl peptidase-4 inhibition by Pterocarpus marsupium and Eugenia jambolana ameliorates streptozotocin induced Alzheimer's disease. Behav Brain Res 2014; 267: 55-65

[78] Wang F, Yu G, Zhang Y, Zhang B, Fan J. Dipeptidyl peptidase IV inhibitory peptides derived from oat (Avena sativa L.), buckwheat (Fagopyrum esculentum), and highland barley (Hordeum vulgare trifurcatum (L.) Trofim) proteins. J Agric Food Chem 2015; 63: 9543-9549

[79] Saleem S, Jafri L, ul Haq I, Chang LC, Calderwood D, Green BD, Mirza B. Plants Fagonia cretica L. and Hedera nepalensis K. Koch contain natural compounds with potent dipeptidyl peptidase-4 (DPP-4) inhibitory activity. J Ethnopharmacol 2014; 156: 26-32

[80] González-Abuín N, Martínez-Micaelo N, Blay M, Ardévol A, Pinent M. Grape-seed procyanidins prevent the cafeteria-diet-induced decrease of glucagon-like peptide-1 production. J Agric Food Chem 2014; 62: 1066-1072

[81] González-Abuín N, Martínez-Micaelo N, Margalef M, Blay M, Arola-Arnal A, Muguerza B, Ardévol A, Pinent M. A grape seed extract increases active glucagon-like peptide-1 levels after an oral glucose load in rats. Food Funct 2014; 5: 2357-2364

[82] Sulaiman AA. Effect of single oral dose of proanthocyanidin on postprandial hyperglycemia in healthy rats: A comparative study with sitagliptin. J Intercult Ethnopharmacol 2014; 3: 73-77
[83] Kozuka M, Yamane T, Nakano Y, Nakagaki T, Ohkubo I, Ariga H. Identification and characterization of a dipeptidyl peptidase IV inhibitor from aronia juice. Biochem Biophys Res Commun 2015; 465: 433-436

[84] Jafri L, Saleem S, Calderwood D, Gillespie A, Mirza B, Green BD. Naturally-occurring TGR5 agonists modulating glucagon-like peptide-1 biosynthesis and secretion. Peptides 2016; 78: 51-58

[85] Tsoukalas M, Muller CD, Lobstein A, Urbain A. Pregnane glycosides from Cynanchum marnierianum stimulate GLP-1 secretion in STC-1 cells. Planta Med 2016; 82: 992-999

[86] Tsoukalas M, Psichas A, Reimann F, Gribble FM, Lobstein A, Urbain A. Pregnane glycosides from Cynanchum menarandrense. Steroids 2017; 125: 27-32

[87] Kim K, Lee YM, Rhyu MR, Kim HY. Spergularia marina induces glucagonlike peptide- 1 secretion in $\mathrm{NCl}-\mathrm{H} 716$ cells through bile acid receptor activation. J Med Food 2014; 17: 1197-1203

[88] Suh HW, Lee KB, Kim KS, Yang HJ, Choi EK, Shin MH, Park YS, Na YC, Ahn KS, Jang YP, Um JY, Jang HJ. A bitter herbal medicine Gentiana scabra root extract stimulates glucagon-like peptide-1 secretion and regulates blood glucose in $d b / d b$ mouse. J Ethnopharmacol 2015; 172: 219-226

[89] González-Abuín N, Martínez-Micaelo N, Blay M, Green BD, Pinent M, Ardévol A. Grape-seed procyanidins modulate cellular membrane potential and nutrient-induced GLP-1 secretion in STC-1 cells. Am J Physiol Cell Physiol 2014; 306: C485-C492

[90] Casanova-Martí À, Serrano J, Portune KJ, Sanz Y, Blay MT, Terra X Ardévol A, Pinent M. Grape seed proanthocyanidins influence gut microbiota and enteroendocrine secretions in female rats. Food Funct 2018; 9: 1672-1682

[91] Tani T, Nishikawa S, Kato M, Tsuda T. Delphinidin 3-rutinoside-rich blackcurrant extract ameliorates glucose tolerance by increasing the release of glucagon-like peptide-1 secretion. Food Sci Nutr 2017; 5: 929-933

[92] Qiu J, Zhu H, Liu P, Wang J, Lu L. Protective effects of dietary polyphenols from black soybean seed coats on islet and renal function in streptozotocin-induced diabetic rats. J Sci Food Agric 2018; 98: 2350-2359

[93] Tunnicliffe JM, Eller LK, Reimer RA, Hittel DS, Shearer J. Chlorogenic acid differentially affects postprandial glucose and glucose-dependent insulinotropic polypeptide response in rats. Appl Physiol Nutr Metab 2011; 36: 650-659

[94] Perfumi M, Arnold N, Tacconi R. Hypoglycemic activity of Salvia fruticosa Mill. from Cyprus. J Ethnopharmacol 1991; 34: 135-140

[95] Azevedo MF, Lima CF, Fernandes-Ferreira M, Almeida MJ, Wilson JM, Pereira-Wilson C. Rosmarinic acid, major phenolic constituent of Greek sage herbal tea, modulates rat intestinal SGLT1 levels with effects on blood glucose. Mol Nutr Food Res 2011; 55 (Suppl. 1): S15-S25

[96] Zhang Q, Xiao X, Li M, Li W, Yu M, Zhang H, Ping F, Wang Z, Zheng J. Berberine moderates glucose metabolism through the GnRH-GLP-1 and MAPK pathways in the intestine. BMC Complement Altern Med 2014; 14: 188

[97] Yang L, Yao D, Yang H, Wei Y, Peng Y, Ding Y, Shu L. Puerarin protects pancreatic $\beta$-cells in obese diabetic mice via activation of GLP-1R signaling. Mol Endocrinol 2016; 30: 361-371

[98] Guo LX, Xia ZN, Gao X, Yin F, Liu JH. Glucagon-like peptide 1 receptor plays a critical role in geniposide-regulated insulin secretion in INS-1 cells. Acta Pharmacol Sin 2012; 33: 237-241

[99] Fan H, Li TF, Gong N, Wang YX. Shanzhiside methylester, the principle effective iridoid glycoside from the analgesic herb Lamiophlomis rotata, reduces neuropathic pain by stimulating spinal microglial $\beta$-endorphin expression. Neuropharmacology 2016; 101: 98-109

[100] Go HK, Rahman MM, Kim GB, Na CS, Song CH, Kim JS, Kim S], Kang HS. Antidiabetic effects of yam (Dioscorea batatas) and its active constituent, allantoin, in a rat model of streptozotocin-Induced diabetes. Nutrients 2015; 70: 8532-8544 
[101] Hu ML, Rayner CK, Wu KL, Chuah SK, Tai WC, Chou YP, Chiu YC, Chiu KW, Hu TH. Effect of ginger on gastric motility and symptoms of functional dyspepsia. World J Gastroenterol 2011; 17: 105-110

[102] Samad MB, Mohsin MNAB, Razu BA, Hossain MT, Mahzabeen S, Unnoor N, Muna IA, Akhter F, Kabir AU, Hannan JMA. [6]-Gingerol, from Zingiber officinale, potentiates GLP-1 mediated glucose-stimulated insulin secretion pathway in pancreatic $\beta$-cells and increases RAB8/ RAB10-regulated membrane presentation of GLUT4 transporters in skeletal muscle to improve hyperglycemia in Lepr $^{\mathrm{db} / \mathrm{db}}$ type 2 diabetic mice. BMC Complement Altern Med 2017; 17: 395

[103] Andersson U, Berger K, Högberg A, Landin-Olsson M, Holm C. Effects of rose hip intake on risk markers of type 2 diabetes and cardiovascular disease: a randomized, double-blind, cross-over investigation in obese persons. Eur J Clin Nutr 2012; 66: 585-590

[104] Vallianou NG, Evangelopoulos A, Kazazis C. Resveratrol and diabetes. Rev Diabet Stud 2013; 10: 236-242

[105] Brasnyó P, Molnár GA, Mohás M, Markó L, Laczy B, Cseh J, Mikolás E, Szijártó IA, Mérei A, Halmai R, Mészáros LG, Sümegi B, Wittmann I. Resveratrol improves insulin sensitivity, reduces oxidative stress and activates the Akt pathway in type 2 diabetic patients. Br J Nutr 2011; 106: 383-389

[106] Törrönen R, Sarkkinen E, Niskanen T, Tapola N, Kilpi K, Niskanen L. Postprandial glucose, insulin and glucagon-like peptide 1 responses to sucrose ingested with berries in healthy subjects. Br J Nutr 2012; 107: $1445-1451$

[107] Liu CY, Huang C], Huang LH, Chen IJ, Chiu JP, Hsu CH. Effects of green tea extract on insulin resistance and glucagon-like peptide 1 in patients with type 2 diabetes and lipid abnormalities: a randomized, double-blinded, and placebo-controlled trial. PLoS One 2014; 9: e91163

[108] Castro-Acosta ML, Stone SG, Mok JE, Mhajan RK, Fu Cl, Lenihan-Geels GN, Corpe CP, Hall WL. Apple and blackcurrant polyphenol-rich drinks decrease postprandial glucose, insulin and incretin response to a highcarbohydrate meal in healthy men and women. J Nutr Biochem 2017; 49: 53-62

[109] Boix-Castejón M, Herranz-López M, Pérez Gago A, Olivares-Vicente M, Caturla N, Roche E, Micol V. Hibiscus and lemon verbena polyphenols modulate appetite-related biomarkers in overweight subjects: a randomized controlled trial. Food Funct 2018; 9: 3173-3184. Erratum in: Food Funct 2018; 9: 4037

[110] Zanzer YC, Plaza M, Dougkas A, Turner C, Östman E. Black pepperbased beverage induced appetite-suppressing effects without altering postprandial glycaemia, gut and thyroid hormones or gastrointestinal well-being: a randomized crossover study in healthy subjects. Food Funct 2018; 9: 2774-2786 